\title{
Synagogue Decorations in Present-Day Ukraine: Practice in Preservation of Cultural and Artistic Heritage
}

\author{
Eugeny Kotlyar - Lyudmyla Sokolyuk - Tetiana Pavlova
}

Prof. Eugeny Kotlyar, PhD

Kharkiv State Academy of Design and Arts

Department of Monumental Paintings

Vul. Mystetstv, 8

61002 Kharkiv

Ukraine

e-mail: eugeny.kotlyar@gmail.com

Prof. Lyudmyla Sokolyuk, Dr hab.

Kharkiv State Academy of Design and Arts

Department of Theory and History of Arts (Head of)

Vul. Mystetstv, 8

61002 Kharkiv

Ukraine

e-mail: sokolyuk_1@ukr.net

Assoc. Prof. Tetiana Pavlova, Dr hab.

Kharkiv State Academy of Design and Arts

Department of Visual Practice (Head of);

Vul. Mystetstv, 8

61002 Kharkiv

Ukraine

e-mail: pavlovat@yahoo.com

To the blessed memory of Scholar, Professor of Architecture,

Head of the Committee on Preserving the Jewish Heritage of Ukraine

Genrikh Iosifovich Filvarov

(1927-2015)

Muzeológia a kultúrne dedičstvo, 2020, 8:4:111-136

DOI: $10.46284 / \mathrm{mkd} .2020 .8 .4 .8$

Synagogue Decorations in Present-Day Ukraine: Practice in Preservation of Cultural and Artistic Heritage There are approximately ten historical synagogue buildings left in Ukraine today which continue, to varying extents, to preserve their original wall paintings and decoration. A number of these were only recently discovered. The attempts underway, beginning in the early $2000 \mathrm{~s}$, to preserve as well as uncover old paintings often produce the opposite effect, destroying authentic works. The cultural significance of these historical landmarks requires that they be included in a single international register, along with supervision and an agreed upon preservation program designed individually for each. Synagogue wall paintings will inevitably perish unless ways of transferring this heritage are sought that will move these works to a different and more reliable "medium of cultural memory". Different, innovative approaches to museum preservation and ways of presenting these works to public view are called for. Among the tried and tested options are: reconstructing old synagogue interiors which contain wall or ceiling paintings; using motifs taken from the original paintings in new works being produced for the Jewish community; and work on exhibition projects, catalogues and two-dimensional reconstruction models.

Keywords: Ukraine, synagogue wall paintings, state, conservation, presentation 


\section{The historical heritage of synagogue wall paintings and its condition today ${ }^{1}$}

To date, synagogue wall paintings comprise a relatively unknown - and, indeed, a nearly erased - element of Jewish culture and art; yet the world of Eastern European Jewry of the pre-Nazi period remains inconceivable without it. It is only in the last few decades that contemporary research has begun to delve into this area, attempting to bridge the chasm separating our understanding of this tradition, its evolution, hermeneutics, iconography and styles, from the potential originally invested in synagogue mural painting decoration in the past. The gap is a result of the catastrophic loss of the tradition as once embodied in the hundreds of synagogue buildings which have been destroyed by either human interference or the passage of time in the course of the twentieth century. This situation is the rule in virtually all of Eastern Europe, though some isolated regions form an exception, such as the Moldovan lands in Romania, where a large number of synagogues containing late paintings which date from the first half of the twentieth century have been preserved.

Since the beginning of the twenty-first century, numerous publications have appeared with a focus on issues in Jewish art and material culture. These texts have enabled the world community to appreciate the extent of the loss of the Jewish heritage, the weathering ruins and vacant dilapidated synagogue buildings, the remnants of precious and semi-erased painting decoration - all of these being the traces of a great and departed Jewish civilization, with which something needs to be done. As early as 2000, Rivka and Ben-Zion Dorfman, in their well-known work on Synagogues without Jens, wrote about the selective approach to costly restoration work to be done on the more significant synagogues, and the more modest approach to other landmarks needing to be clearly labelled as former synagogues which would subsequently be "used for respectable social purposes." ${ }^{2}$ The same authors were also the ones who labelled this area as a sphere for "wise investments", singling out two primary motives for the preservation of this heritage: the cultural (the memory of the Jewish past) and the social (developing the tourism infrastructure). These deliberations were mostly concerned with the central and southeastern regions in Europe, without bearing upon the primary setting of Eastern European Jewish history in what is today Poland, Ukraine and Belarus. Their focus was overall on synagogues as historical and architectural monuments which contained wall and ceiling paintings along with other elements of décor.

As of today, we can confirm that meticulous preservation of the surviving Jewish heritage in many countries of Eastern Europe, such as Poland, Czechia, Slovakia, Hungary and others, has facilitated the restoration of surviving works, their museification, and their becoming part of an identifiable and clearly demarked part of the culturally diverse landscape of these countries. All this is true quite regardless of the fact that in many of these regions almost no Jews remain today! This was the upshot of the appreciation arrived at by these states, by Jewish institutions, and by the international community, including the professional community, of the value of this cultural material and the importance of its memorialization so as to ensure a "historical trace",

\footnotetext{
${ }^{1}$ We are grateful to Elen Miriam Rochlin (Jerusalem) for her translation of the article into English. A glossary of Hebrew and Yiddish terms is provided at the end of the article.

${ }^{2}$ DORFMAN, Rivka and Ben-Zion. Synagogues without Jews and the Communities that Built and Used Them. Philadelphia: The Jewish Publication Society, 2000), p. 4-7.
} 
an objectification of memory, and the construction of identity. ${ }^{3}$ To date, these monuments have been included in many guidebooks and lists of landmarks in particular cities and countries as part of their own heritage and treasure, an element of the totality of Eastern European Jewish culture.

The situation with synagogue wall paintings proved thornier, insofar as restoration strategies depended on the seriousness and extent of the losses in question, as well as the purposes for which the buildings would later be designated. Synagogues often contained paintings dating from different periods, with each stratum constituting a piece of historical and artistic testimony to the times of its creation, in need of being preserved and individually conveyed to later visitors. Thus the question of whether to uncover the lowest - older - stratum, dating from, say, the 1700s, at the cost of destroying the upper layer created in the early 1900s would always call for a careful weighing and consideration of alternatives. Restoration techniques also varied depending on whether the synagogue in question was to be made into a museum or to remain - or to once again become - a house of prayer. In the first case, proponents of academic restoration techniques could suggest a variety of technologies and approaches to preserving the old strata, making up for lost fragments with new painting or decorative images which would be different from the authentic painted original. In cases where it was to be a place of worship, the building would be returned to the community, which would then make its own decisions about whether to preserve the polychrome compositions in their original, often not very presentable condition, or to modernise the decorative elements to bring them into greater conformity with today's norms and tastes. ${ }^{4}$ Clearly enough, all this would have a great impact on the fate of the paintings themselves.

However, as Israeli researcher Prof. Ilia Rodov has pointed out, as time passed, synagogue wall paintings naturally lost their artistic wholeness and original look simply due to the degredations of time, notwithstanding restorers' attempts notwithstanding to preserve them intact in their uninterferred with, often damaged or altered state. This is why, in addition to maintaining the physical remnants of the paintings, a complex assembly of visual, historical, folkloric and other types of evidence is required, which would provide an adequate impression of the system of interior decoration in any one particular synagogue and of the phenomenon of synagogal decoration as a whole. ${ }^{5}$ These issues were the subject of discussion at a recent seminar organised by the Center for Jewish Art at the Hebrew University of Jerusalem, which focused on the problem of researching, preserving and presenting synagogue wall and ceiling paintings to view. ${ }^{6}$ Another reason for organizing this forum and open discussion was the presentation of the extensive project of the electronic Catalogue of Central and Eastern European synagogue wall paintings, conducted under the auspices of the Center for Jewish Art using materials collected on research expeditions over a period of more than 20 years (project

\footnotetext{
${ }^{3}$ Theoretical grounding for the issue of the impact which memory of the past has upon the construction of cultural identities is provided in the work of the German Egyptologist Jan Assmann, see: АССМАНН, Ян. Культурная память. Письмо, память о прошлом и политическая идентичность в высоких культурах Аревности. М.: Языки славянской культуры, 2004.

${ }^{4}$ RODOV, Ilia. Ars Brevis, Vita Longa: On Preservation of Synagogue Art. In: Studia Hebraica, 2011, no. 9-10 (2009-2010), p. 93-98.

${ }^{5}$ Ibid., p. 98-99.

${ }^{6}$ The conference took place on 14-16 September 2016, bringing together more than 20 leading specialists from many countries, whose work today determines the course taken in this area of Jewish art.
} 
authors Boris Khaimovich, Vladimir Levin). ${ }^{7}$ As per the authors' conception of the project, the catalogue encompasses paintings created as a part of traditional folk Jewish culture, with the exception of paintings in buildings constructed in a style associated with historicism. The purpose of this kind of interactive cataloguing of synagogue wall paintings is to document the visual and verbal testimony of items both preserved and lost, along with compositional themes and inscriptions within the paintings. This an open-ended project, which will continue to grow and extend its scope with the addition of new materials as they are uncovered, thus creating a foundation for future studies. In essence it is comparable with the extant program for searching for Holocaust victims, researching their fates and eternalising their memory.

The author of the present paper made a special report at this academic gathering, completing the overall picture with updated information on the condition of synagogue paintings in Ukraine. But a considerable number of finds have surfaced since the Jerusalem seminar; they have extended our understanding of the ongoing processes and of the perspectives stretching into the future in this area, and sum up their development at the current stage. All this forms the foundation of the present study, which should be prefaced with a certain preamble.

Everything noted thus far largely concerns lands to the west of former Soviet territory. For certain well-known reasons, moving away from the centre of Europe eastward, especially into the post-Soviet space, the situation with the preservation of the Jewish heritage and synagogue wall paintings (and with cultural landmarks overall) changes in far from the best way. The situation in Ukraine is no exception; it requires close attention and an immediate response, in order for us not to lose those crumbs which have still been retained and await our involvement. This action must, however, be thoughtful, delicate and professional.

Today, given the current stage of the research and familiarity with the archives and museum resources available in the Ukrainian region, we can count the surviving elements of UkranianJewish heritage and assess the magnitude of the irreparable losses. If, on a contemporary map of Ukraine, we mark the locations of all the synagogues with wall and ceiling paintings ever known to have existed in these lands - this means over a timespan of at least two-and-a-half centuries, extending from the late seventeenth century into the 1940 s - we would count at least fifty sites. Based on what we know of Jewish demographics and the centuries-long process in which the synagogue wall painting tradition spread, the real number may have been much higher, but we can at best form only an indirect impression of this. Many towns and shtetls were home to dozens of synagogues and houses of prayer, many of them containing wall and ceiling paintings, as was the case in Lviv and in Chernivtsi; this is confirmed by both verbal testimony and surviving artefacts.

Most of the wooden and stone synagogues containing paintings were located in Right-Bank and Western Ukraine, part of the territory of the former Polish-Lithuanian Commonwealth, Austria-Hungary, Romania, and a number of Eastern European states. The cultural uniqueness of these lands had an impact on the distinctive regional features of the painted decoration of the synagogues, which conformed to one single tradition overall.

The calamitous developments of the twentieth century, including wars, the Holocaust, atheism, the Soviet regime's antisemitism, and the careless handling of precious heritage items in subsequent decades, all account for the fact that the map of Ukraine today retains few more

\footnotetext{
${ }^{7}$ See: The Catalogue of Wall Paintings in Central and East European Synagogues http://cja.huji.ac.il/wpc/browser. php? $\operatorname{mode}=$ main $($ accessed 18 October 2019).
} 


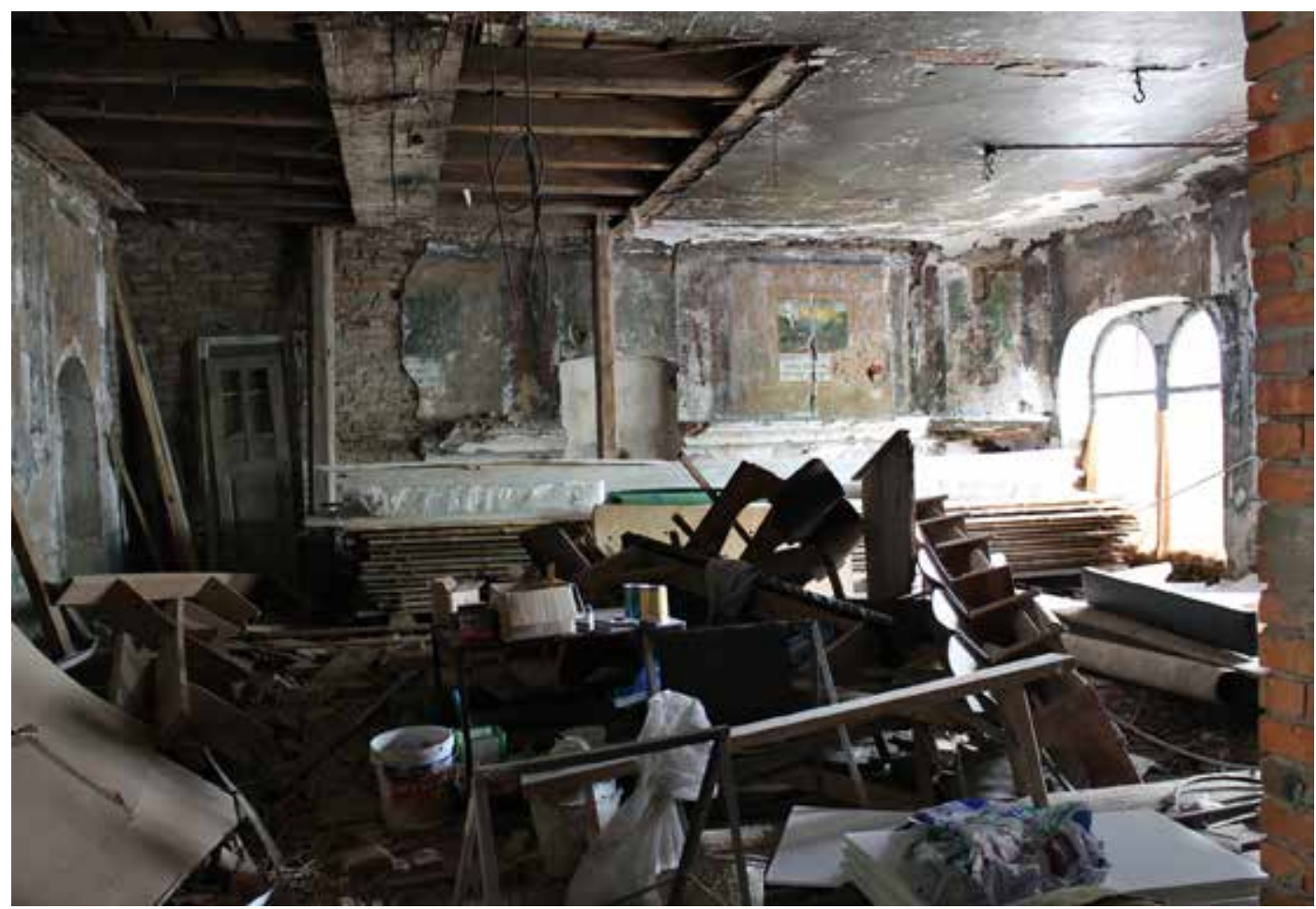

Figure 1: Chernivtsi. Chevra Tehilim Synagogue, turn of twentieth century. Photo by Anna Yamchuk, 2015

than ten sites where old synagogue wall paintings survive at all. ${ }^{8}$ Some of these remaining sites are in deplorable condition and are effectively beyond repair. The Nazi occupation was, unquestionably, the main, though not the only reason for this state of affairs. Ukraine's "achievements" in post-war modernisation saw these buildings stand neglected for decades, without maintenance, or else they were used as warehouses and storage facilities, leading to all the associated problems one might expect with moisture and fungus. The wall paintings here were gradually being destroyed by time. It may seem bizarre today, but other than a few researchers, well-informed connoisseurs and tourists (most of them foreigners), few people entertained the notion that these items were rare surviving memorials of Jewish spiritual culture and art - the fragments of the once high-powered phenomenon of synagogue decoration.

Traveling through former Jewish shtetls and larger towns, even today one can often enough come upon picturesque epic ruins of synagogues - deserted, overgrown, or else piled over with discarded items and debris - their interiors bearing traces of paintings which have been smashed or come unstuck due to moisture and which are of little interest to anybody. Examples of buildings in this state include the half-destroyed synagogue in Stryj (1817) and the abandoned building of the Old Synagogue in Chortkiv (1771). The Chortkiv synagogue still preserves sufficient fragments of its decor to provide an impression of the former painting scheme in the prayer hall. ${ }^{9}$

Another instance is in the Hasidic shul, Chevra Tehilim in Chernivtsi. A Christian Baptist prayer house occupies this space today. In the crumbling strata of paint, the visitor of today

\footnotetext{
${ }^{8}$ All the Ukranian synagogues which contained wall paintings listed in this article were studied and recorded by the author Eugeny Kotlyar between 2003 and 2016.

${ }_{9}^{9}$ Синагоги України: Вісник Інституту УкрзахіАпроектреставрація, Аьвів, 1998, no. 9, p. 140-141, $166-167$.
} 
may, with painstaking efforts, be able to discern certain narrative compositions and partly envision the painting scheme as a whole (Figure 1). ${ }^{10}$ These historic paintings are disintegrating before our very eyes as the second storey, where the prayer hall of the synagogue was once situated, is constructed anew.

Almost nothing remains of the paintings in the synagogue of Rabbi Israel Friedmann, the Tzaddik of Sadygora (Chernivtsi). 2016 saw the reconstruction of the synagogue, at a speed unheard of in undertakings of this kind; moreover, the authors and the sponsors of the project tried to make the architecture and the decoration reflect, as closely as possible, the reality extant in the past. ${ }^{11}$ Considering the miniscule traces of the original wall paintings which had survived, the connection between the new and the old paintings became rather theoretical and primarily symbolic, making this case symptomatic of the situation of many others.

In effect, there are only five buildings left to discuss, all of them former synagogues which have again become functional and where a unified painting ensemble may still be seen in the prayer hall in a state of relative completeness. They all date from the first half of the twentieth century and are located in Eastern Galicia (Lviv), Bukovina (Chernivtsi, Novoselitsa) and the Trans-Carpathian region (Uzhgorod, Khust).

Three of these monuments preserve narrative-symbolic decoration typical of the traditional synagogues of Eastern Europe. This tradition took shape in the course of earlier centuries, but continued to evolve over time. The present examples are the Tzori Gilead Synagogue in Lviv, the Beit Tefilah Benyamin Synagogue in Chernivtsi, and the New Great Synagogue in Novoselitsa (Northern Bukovina region). Tzori Gilead and Beit Tefilah Benyamin Synagogues, in Lviv and Chernivtsi respectively, are both still active today; the New Great Synagogue in Novoselitsa is not. The remaining two sites, in Uzhgorod and Khust (Trans-Carpathian region), provide instances of a different type of decoration: ornamentation typical of Reform temples, bearing a stylistic kinship to the Neolog synagogues in Hungary, constructed by the proponents of modernisation. The synagogue in Khust is currently functioning as a synagogue; ${ }^{12}$ the one in Uzhgorod is not.

It bears noting that a number of unique sites have been discovered and documented in recent years, even though the general tendency at present is for the surviving remnants of synagogue decoration to disappear entirely. One of sites, the New Great Synagogue in Novoselitsa, Chernivtsi Oblast, was only recently discovered, when its wall paintings were uncovered beneath more recent layers of plaster in 2009. ${ }^{13}$ Judging by the preserved inscriptions with donors' names, these wall paintings were created in 1919-1920. The name which appears next to the date of

\footnotetext{
${ }^{10}$ The study of these wall paintings, along with an attempt to reconstruct the entire system of painting decoration, appears in these publications: KUSCHNIR, Mykola, KOTLYAR, Eugeny; YAMCHUK, Anna (eds) "How Goodly Are Thy Tents, O Jacob..." Wall Paintings in Bukovinian Synagogues. Catalogue of the Exhibition. Chernivtsi-Kyiv: The Chernivtsi Museum of the History and Culture of Bukovinian Jews; Spirit and Letter, 2016, p. 26-39; KHAIMOVICH, Boris. The Murals in the Novoselitsa Synagogue. Kyiv: Spirit and Letter, p. 51-56.

11 The authors are grateful to Dr Joseph Zissels, Chairman of the VAAD of Ukraine, and Mikhail Kraiz, leader of the synagogue reconstruction project, for acquainting him with the course of reconstruction of the building in October 2016 and detailing the project implementation process.

${ }^{12}$ Синагоги України, ref. 8, p. 149-150, 154-155.

${ }^{13}$ АИФШИЦ, Юлий. На грани забвения. In: Егупець. Київ: Аух і літера, 2010, no. 19, p. 401-423.
} 


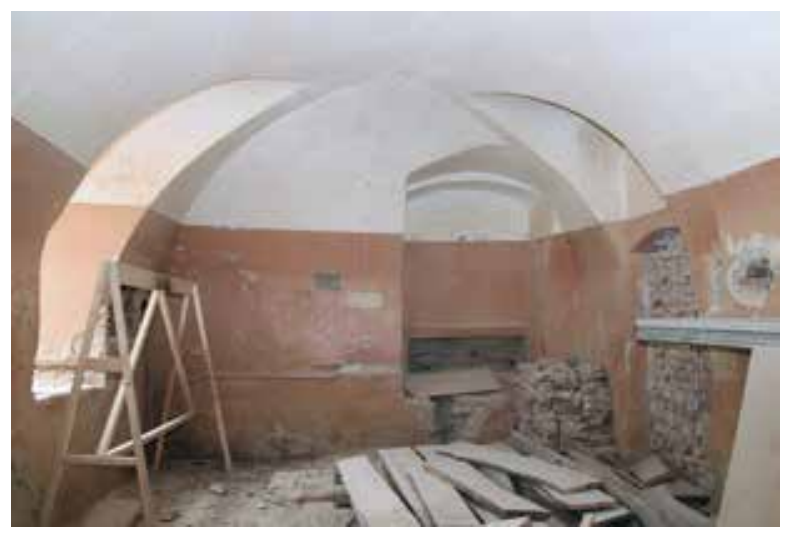

Figure 2: Chernivtsi. The minor hall of the synagogue Groyse Shil. Photo by Eugeny Kotlyar, 2010

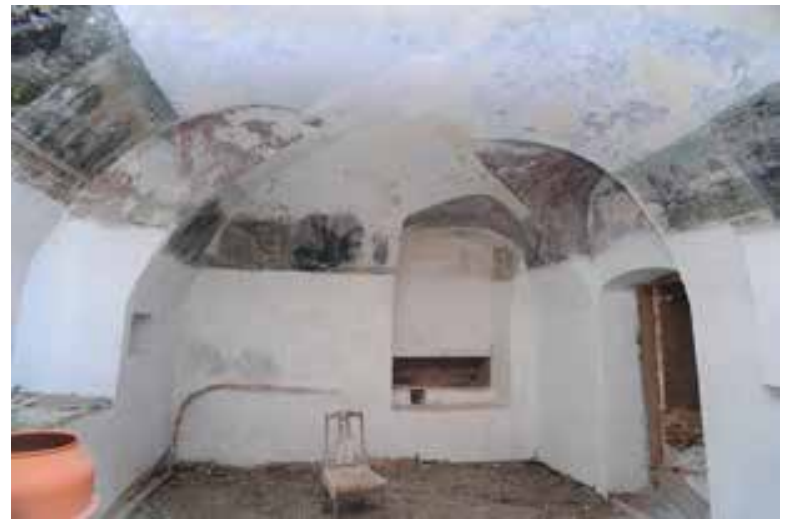

Figure 3: Chernivtsi. The minor hall of the synagogue Groyse Shil. Wall paintings, late 1930s. Discovered in 2013.

Photo by Anna Yamchuk, 2015

departure from painting strata dating from various periods, the differences are also indicative of different generations. This is the case with the vestiges of the wall and ceiling paintings in the abovementioned Chevra Tehilim Synagogue of the Vizhnitz Hasidim; the same can be said of the relatively complete painting cycle in the smaller hall of Groyse Shil Synagogue, which was cleared of debris in 2013 (Figures 2, 3). The paintings in Groyse Shil date from the 1930s, and are the work of the local painter Yitzhak Issachar Aizikovich (1882-1944), who left his name in the inscription in one of the compositional schemes. The fragments, found in 2015, of a painting stratum in the former Choral Synagogue in the town of Beregovo in the TransCarpathian region may be associated with the same group of works. The style represented in

\footnotetext{
${ }^{14}$ For details on the wall paintings in the Novoselitsa synagogue, see: КОТАЯР, Евгений. Росписи синагог Северной Буковины в контексте восточноевропейской традиции. In: Judaica Ukrainica. Peer-reviewed annual Journal in Jewish Studies. Kyiv: The Publishing Center of Kyiv-Mohyla Academy, 2012, vol. 1, p. 227-263; KHAIMOVICH, Boris. "The Work of Our Hands to Glorify". Murals of Beit Tfilah Benyamin Synagogue in Chernovits: Visual Language of Jewish Artist. Kyiv: Spirit and Letter, 2008.

${ }^{15}$ KHAIMOVICH, ref. 9, p. $41-48$.

${ }^{16} \mathrm{KHAIMOVICH}$, ref. 13.

${ }^{17}$ KUSCHNIR, ref. 9. p. 26-55; KHAIMOVICH, ref. 9, p. 51-56.
}

the paintings (which could be the name of the artist or the donor) is Fishman. ${ }^{14}$ Recent research by Boris Khaimovich by a certain master, Groyzgrow from Khotin, in the traditions of the "regional canon" of Boyan Hasidism. ${ }^{15}$ This surviving building features an especially extensive series of late Eastern European synagogue paintings, enabling us to trace the spread of this iconographic system among the synagogues of Northern ukovina.

After the discovery of the Novoselitsa paintings, it became evident that the same scheme served as the model for Benyamin Synagogue in Chernivtsi in the 1930s; before this discovery was made, the synagogue had seemed one of a kind, with the regional origins of its painting decoration impossible to trace. ${ }^{16}$ Two other recently discovered Chernivtsi synagogues display a similar thematic and compositional approach in their painting programme, which was read and expressed in different ways by the masters of the Chernivtsi circle. ${ }^{17}$ Not only that, but, if we take our point of 
these fragments shows them to be kin to the traditions of the wider region, such as the wall paintings of the synagogue in Khust mentioned above. ${ }^{18}$

The discovery of these paintings has provided researchers with unique material, suddenly opening the eyes of the public to the very existence of synagogue decoration as a practice, an artistic field that has not received much recognition or attention in the past. This has highlighted the critical importance of giving some thought to other surviving synagogue buildings in which paintings may be concealed beneath later layers of plaster. These finds can be considered an encouraging sign of the beginning of large-scale study of surviving synagogues throughout Ukraine.

\section{Experience preserving synagogue decoration}

Though an integral part of Jewish heritage, synagogue wall paintings did not attract due attention during the first decades of Ukraine's independence, when the rebirth of Jewish life began. Up until the early 2000s, Jewish communities were more concerned about issues relating to the restitution of former Jewish properties and reconstructing recovered synagogue buildings to serve new needs. Work of this kind was coordinated by the Committee for the Preservation of Jewish Heritage at the VAAD (Association of Jewish Organizations and Communities) of Ukraine, ${ }^{19}$ along with the American Jewish Joint Distribution Committee, which provided communities with legal, practical and financial assistance. ${ }^{20}$ In the early 1990 s, a special program was set in operation to document synagogues located in Ukraine; it was implemented by the Center for Jewish Art at the Hebrew University of Jerusalem and continued to operate into the first decade of the twenty-first century. In the course of this period, research was undertaken pertaining to some four hundred synagogues, including a number where painting strata have been preserved. This work was done in coordination with the Ukrzabidproyektrestavratziya project (Western Ukrainian Reconstruction Project) in Lviv, whose staff prepared a special publication in 1998 about the synagogues of Ukraine with descriptions of more than 120 synagogues, including an evaluation of the condition of the surviving decorations. ${ }^{21} \mathrm{~A}$ comprehensive study of Jewish landmarks, including Ukrainian synagogues, was published in 2005 under the supervision of Samuel Gruber as part of the open international program of the US Commission for the preservation of American heritage abroad. ${ }^{22}$ But these organizations' work had no real impact on the project of preserving synagogue wall and ceiling paintings, due to the difficulty of combining the academic format of the research with the complex set of factors impacting the practical work that needed to be done locally. Considered in the larger scheme of things, the wall paintings did not at the time attract the attention they deserved, even though their existence was recorded in the process of these projects' work, as well as in the records of fieldwork expeditions kept by individual researchers and organised study expedition

\footnotetext{
${ }^{18}$ I thank Vladimir Katz, leader of the Jewish religious community of the town of Khust, for the guided tour and hospitality he showed me by accompanying me to Jewish sites, landmarks, and synagogues of Trans-Carpathia, as well as for his assistance in filming the interior of the Khust synagogue.

19 ФИАЬВАРОВ, Генрих. Историко-градостроительные особенности сохранения еврейского культурного наследия в Украине. In: Єврейська історія та культура в Україні: Матеріали конференції, Київ, 8-9 грудня, 1994. Київ: Асоціація юдаїки України, 1995, сс. 193-195.

${ }^{20}$ BEIZER, Michael. Our Legacy: The CIS Synagogues, Past and Present. Jerusalem: Gesharim - Moscow: Bridges of Culture, 2002, p. 53-82.

${ }^{21}$ Синагоги України, ref. 8.

${ }^{22}$ GRUBER, Samuel (ed.) Jewish Cemeteries, Synagogues and Mass Grave Sites in Ukraine. The Report. Washington: US Commission for the Preservation of America's Heritage Abroad, 2005.
} 
groups.

It is only during the last decade that the remaining sites containing synagogue wall paintings have become the object of special attention among researchers (such as Boris Khaimovich, Bracha Yaniv, Ilia Rodov, Samuel Gruber, Sergey R. Kravtzov, Vladimir Levin, Eugeny Kotlyar and others) and the Jewish public, as represented by major Jewish organizations, local communities and individual enthusiasts. This change was brought about by the new stage of development reached by Jewish life in Ukraine, which made the goal of the preservation and musealisation of Jewish heritage particularly pertinent. Aiming for this goal was in keeping with international practice, openness and the spirit of collegiality. At the same time, it is important to assess the experience accumulated in preservation work on surviving paintings in synagogue interiors. The experience accumulated to date of preserving extant synagogue paintings involves a variety of approaches, the choice of which is dependent on the particular situation in each case. In nearly all cases, this means an intricate compromise between the competing desires to reveal, preserve and renew old works. Today we are in a position to think through the achievements and the mistakes made in this area, given how often overly hasty or inadequately considered strategies have led to destructive consequences that are either obvious or latent. Let us take a look at a few telling examples involving different approaches to this problem.

1. Comprehensive reconstruction, with refurbishment of some of the paintings and restoration of individual painting cycles

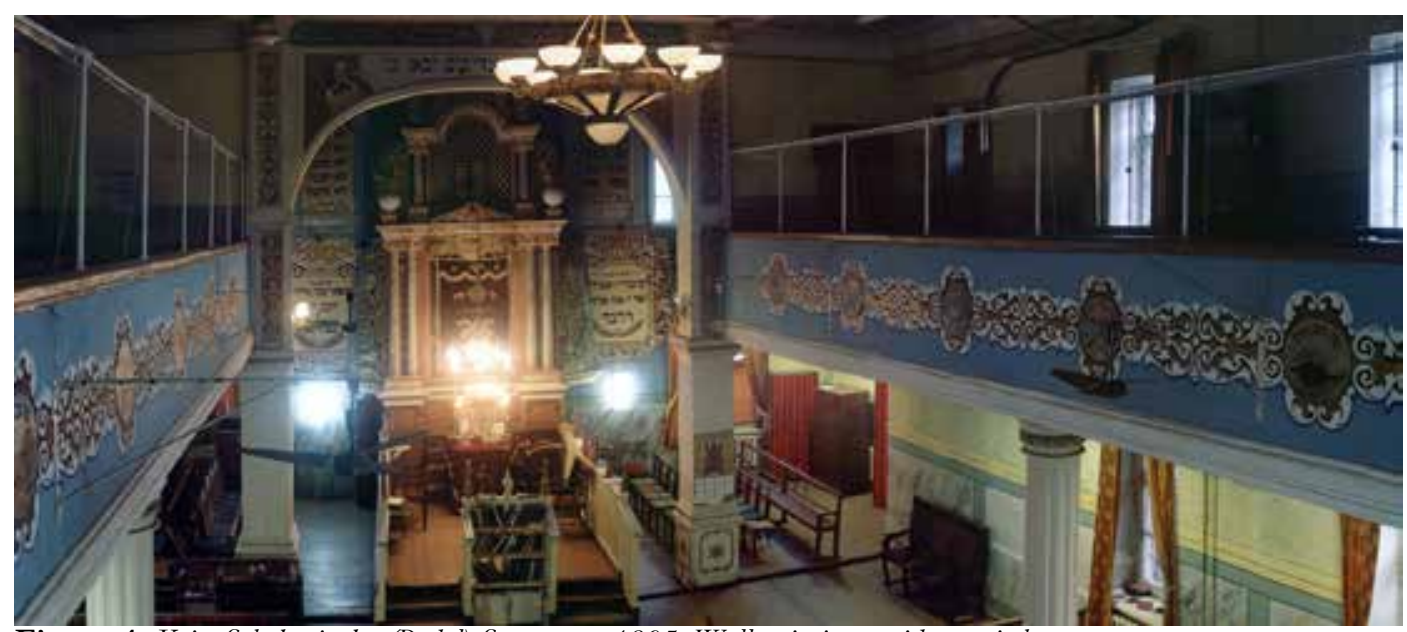

Figure 4: Kyiv. Schekovitzka (Podol) Synagogue, 1895. Wall paintings, mid-twentieth century.

Photo by Eugeny Kotlyar, 1997

This approach was resorted to in the reconstruction of Schekovitzka Synagogue in Podol, Kyiv, built in $1895 .^{23}$ The wall paintings surviving to date, according to the testimony of its oldest members, are from the mid-1900s. The last refurbishment took place in 2003, when the building as a whole was reconstructed (Figure 4, 5). ${ }^{24}$

A roundtable discussion - which included leaders of Jewish organizations, prominent

\footnotetext{
${ }^{23}$ КААЬНИЦКИЙ, Михаил. Еврейские адреса Киева. Киев: Аух і Аітера, 2012, р. 133-142.

${ }^{24}$ КОТАЯР, Евгений. Образ еврейского Ренессанса. К реконструкции ГАавной синагоги г. Киева. In: Ватерпас. Харьков, 2003, nо. 45, p. 34-38.
} 


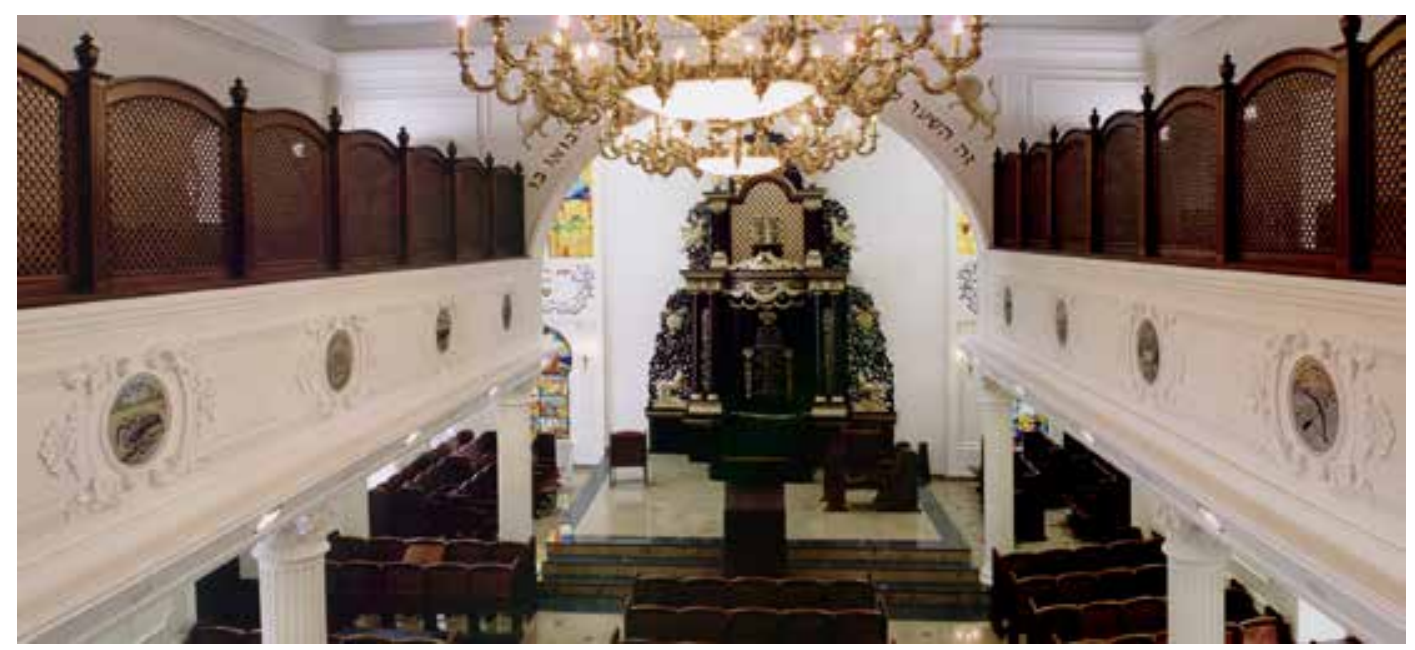

Figure 5: Kyiv. Schekovitzka (Podol) Synagogue, 1895. Wall paintings, mid-twentieth century. Refurbished in 2002. Photo by Eugeny Kotlyar, 2003

architects from the Ukrproyektrestavratziya Institute in Kyiv (which had the exclusive right to work with high-status architectural monuments), the Israeli architect-designer Aharon Ostraikher (who later assumed a leading role as a renovator of old synagogues in the Commonwealth of Independent States) and other experts - determined the conceptual framework and the strategy to be adopted in the reconstruction process. Behind the reconstruction efforts lay the desire to recreate the architect's original plan of 1894, which had never been implemented in full. The project's initiators aimed as much as possible to preserve elements which had artistic or historical value, sacrificing whatever required radical renovation. For example, the round inserts with paintings of the signs of the Zodiac, distributed along the balconies of the women's gallery, were preserved and restored, as were the four tondos with animal figures symbolizing religious virtues on the ceiling which were originally made in the 1950s. The architectural-decorative finishing of the interior was completely renovated in the course of the reconstruction, and new decorative elements were added, including the installation of original stained-glass windows (work of the artists Eugeny and Yelena Kotlyar). At the same time, old wall paintings of texts enclosed in frames, ornamentation and images of lions in front of the Torah Ark were entirely replaced with new pieces which were a better fit with the interior, which was now in an entirely different colour scheme. The total makeover of the building obviously required that some elements be given up, based on the understanding that the synagogue as a whole needed a new image as the main synagogue of the city and the country, and the locus of the Chief Rabbi of Ukraine's residence. In this way, a balance was observed between, on the one hand, maintaining the artefacts intact and restoring authentic and particularly valuable elements of the decorative finish, and on the other hand, conducting a carefully weighed and considered renovation of the architectural-artistic synagogue complex in its entirety, emphasizing the original stylistic elements.

\section{Completely repainting the original mural}

This approach can be seen in the case of the functioning Tzori Gilead Synagogue in Lviv, which was built in 1924. Up until 2006, the year when it was last comprehensively renovated, the building preserved its painting decoration, which dated from 1936 and was created by the 


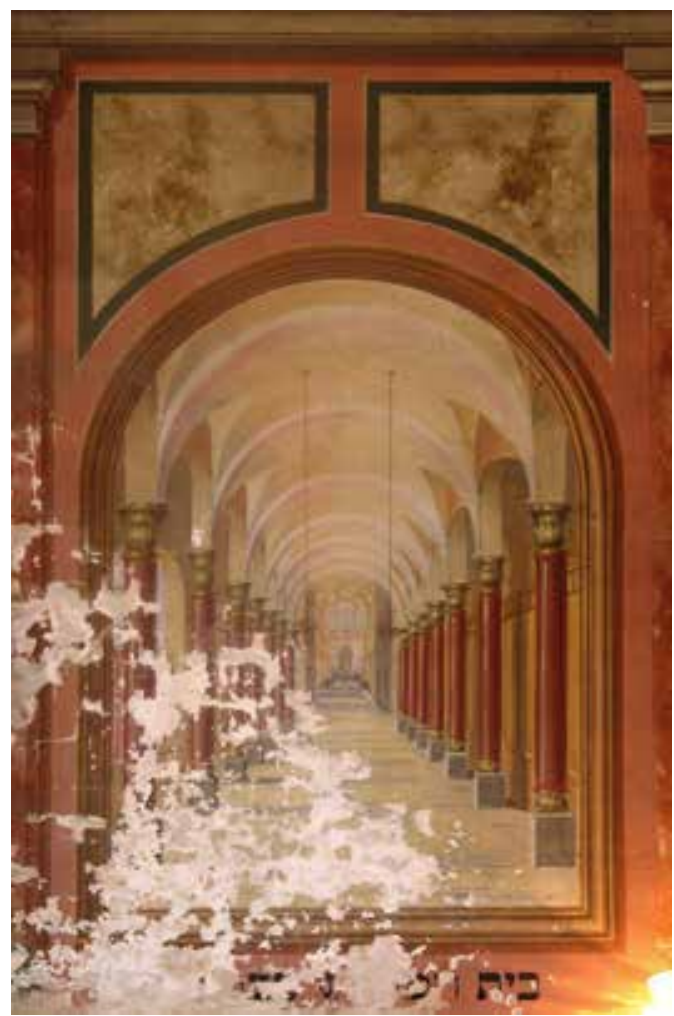

Figure 6: Lviv. Trori Gilead Synagogue. Wall paintings, 1930s. Photo by Eugeny Kotlyar, 2006

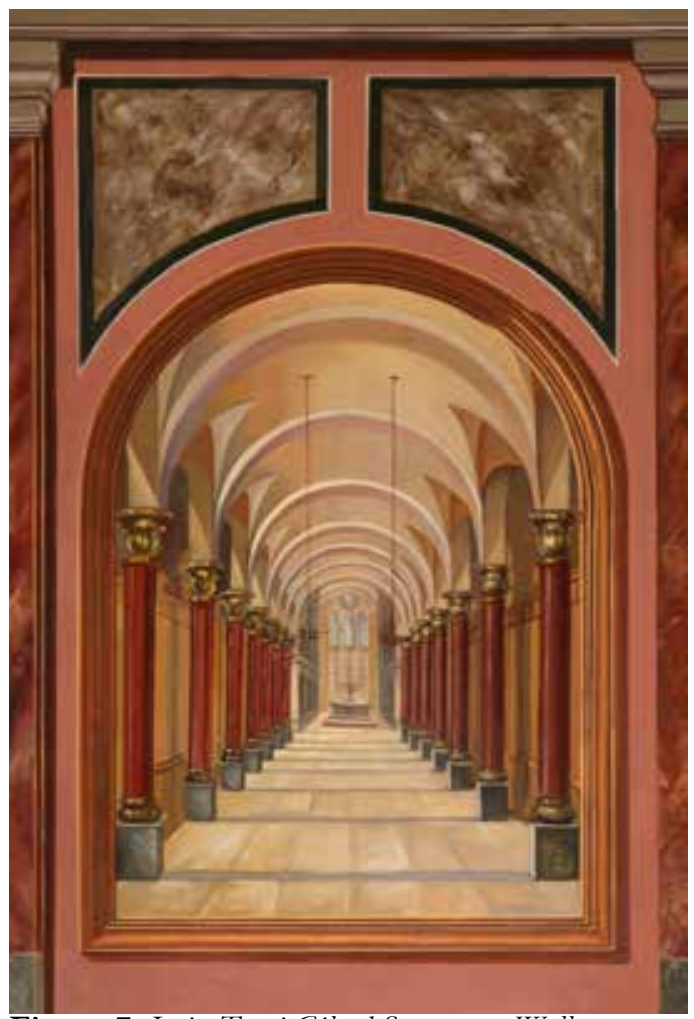

Figure 7: Lviv. Trori Gilead Synagogue. Wall paintings, 1930s. Refurbished the old paintings in 2006.

Photo by Eugeny Kotlyar, 2012

well-known Lviv master, Maksimilian Kugel. Even though the paintings were damaged during the years of Nazi occupation, and later when the building was used as a storage facility, the losses suffered were not so serious that they ruled out traditional restoration methods - which was, in fact, the approach adopted by the synagogue's decision-makers. ${ }^{25}$

The purpose of the reconstruction was to renovate the prayer hall so as to accommodate the needs of the contemporary community. This is why, in addition to the repair work done on the facility and the replacement of the furniture, lighting fixtures and other equipment, the community leaders also refurbished the old paintings, aiming to preserve the historic ambiance and endow the interior with an aura of respectability. Authentic paintings were completely destroyed as a result: the artists simply did the paintings anew, in the process altering compositions and inscriptions which had been partly lost and using a different painting style and colour contrasts which were far in excess of the original. Thus, in the reworked composition, the view of the interior of the Temple in Jerusalem lost the inscription which once sat under it (Figures 6, 7), while the image of the Ark containing the Tablets of the Law was replaced by a menorah. Community leaders had evidently found it simpler to redo old compositions than to devote effort to the painstaking and costly process of restoration, which would in any case have produced less of an effect than the new paintings. This case instantiates the general rule that a functioning synagogue cannot be a museum; it is illustrative of the real dilemma between preserving a historical landmark as a museum piece of sorts, and restoring it so as to make

${ }^{25}$ RODOV, ref. 3, p. 96-98. 
it usable in accord with its initial purpose, with all the inevitable loss of authenticity that this entails.

3. Conserving the paintings in tandem with the complete reconstruction of the building This approach was adopted by Sataniv Synagogue, which dates from the late sixteenth/ early seventeenth century. ${ }^{26}$ Reconstruction has been under way since 2013 and continues at the time of writing. Surviving painting fragments apparently date from the late nineteenth/ early twentieth century. Based on the synagogue's appearance to date, the reconstruction seems to be aimed at providing comprehensive reinforcement and renovation for parts of the building, while conserving and maintaining fragments of the original brickwork, carving and paintings intact, so as to make it possible to use the building as a museum in the future. Surviving painting fragments on the scuncheons have been conserved and marked out by enclosing rectangles. In this way, paintings, along with other old elements have been highlighted by partly plastered over and whitewashed walls, thus underscoring the architectonics of the interior space. This approach is evidently based on the example of Polish synagogue reconstruction, particularly in the Old and the High Synagogues in the Kracow suburb of Kazimezh. Unlike their predecessors, however, the restorers on this project clearly overstepped the limits in their desire "to enliven and make warm the walls of the miserable prayer room" (Rachel BernsteinWischnitzer) by including in it various elements which were in fact alien to it. ${ }^{27}$

We have no issues with the methods used to preserve painting fragments, but questions do arise in connection with many other remakes, such as the folding casements or wooden bimabs (raised platforms) that look strikingly different from those in old photographs. The approaches used here clearly point to an obviously superficial level of awareness of available iconographic material and the absence of dialogic contact with experts. Even more striking is the ostentatious marble floor, the polished wooden doors, the dividers pierced by lacey ChabadLubavitch menorah shapes, and the massive benches girding the prayer hall walls. This alien stylization destroyed the atmosphere of historic agedness and ascetic grandeur in one of the oldest fortress-type synagogues in Ukraine. Around the exterior we see an unwarranted fence, unmotivated by any historical evidence or references, rock-garden flowerbeds, fussy elaborate screens and marquees over the entrances, all of which add kitsch, distorting and devaluing the authentic look of the synagogue and the visual interaction it once had with its surroundings.

\section{Museification of synagogue ruins, uncovering and conserving the painting stratum}

An example of this kind of preservation can be found in the memorial-educational complex titled "Synagogue Space", unveiled in Lviv in September 2016, which includes the ruins of the "Golden Rose", the oldest synagogue in Ukraine, which was constructed in 1582. ${ }^{28}$ The complex is part of an extensive international initiative by Lviv City Council, aimed at the memorialization of Jewish history and victims of the Holocaust, preservation of the common

\footnotetext{
${ }^{26}$ АИФШИЦ, Юлий. Натурные исследования здания синагоги XVII - XIX вв. в г. Сатанове Хмельницкой области. In: История евреев на Украине и в Белоруссии: Экспедиции. Памятники. Находки. СПб.: Петербургский Еврейский университет: Институт исследований еврейской диаспоры, 1994, вып. 2, р. 120-127.

${ }_{27}^{27}$ БЕРНШТЕЙН-ВИШНИЦЕР, Рахиль. Искусство у евреев в Польше и Аитве. In: История евреев в России. Москва: Мир, 1914, т. ХI: История еврейского народа, т. 1, р 394.

${ }^{28}$ For the history of the Golden Rose, see: KRAVTSOV, Sergey. Di Gildene Royze. The Turei Zahav Synagogue in L'viv. Petersberg: Michael Imhof Verlag, 2011, vol. 3.
} 
heritage, and creation of city memory spaces and their inclusion in the contemporary context. ${ }^{29}$ Under the topmost layers of plaster, the synagogue conservation initiative's conservators (from the Ukrproyektrestavratziya Institute) partially uncovered barely discernible traces of ornamentation and inscriptions fitted into the margins of special charts framed by a decorative border. Decoration of this kind was typical of paintings in stone and wooden synagogues of the seventeenth and eighteenth centuries. Unlike the previous case, the project's authors did not attempt to introduce any innovations, but rather created a living and dynamic street space open to dialogue, constructing a "space of silence" in order to preserve a documentary record of the past, conveyed by its grandiose but sparse remnants. An approach along these lines is, in the opinion of the authors, in harmony with UNESCO recommendations on restoring the former image and look of a historical monument, in such a way that enables the realisation of additional projects in the future, which may include the reconstruction of the synagogue itself.

\section{Uncovering and reinforcing the painting stratum}

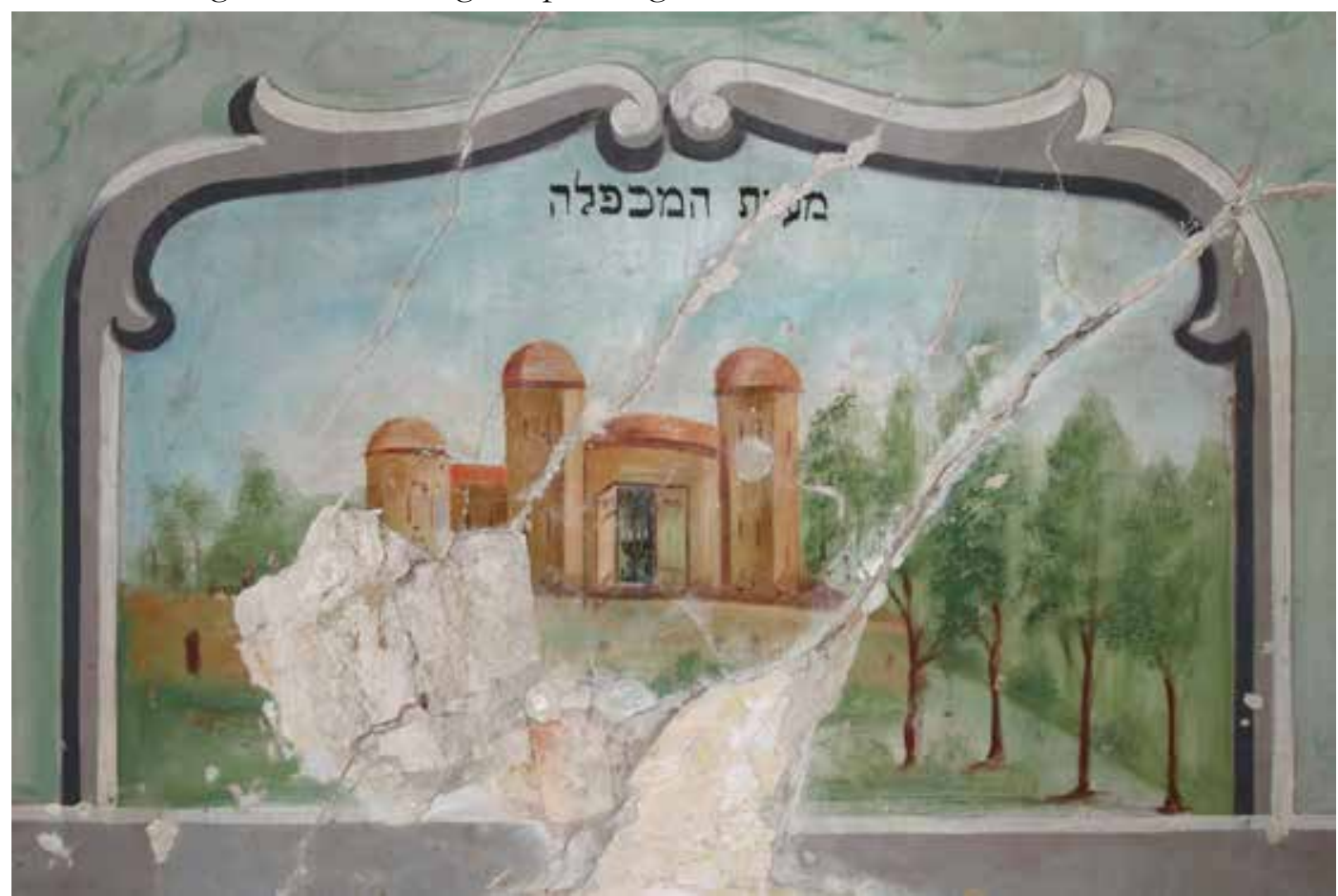

Figure 8: Novoselitsa. New Great Synagogue. The Tomb of the Patriarchs in Hebron: wall paintings, 1919-1920. Discovered in 2009. Photo by Eugeny Kotlyar, 2010

The only example of this approach is the case of the paintings in the abandoned Novoselitsa synagogue, which were discovered under the whitewash in 2008 and made fully visible a year later by Kyiv renovators. ${ }^{30}$ The purpose of clearing away the most recent layers of plaster from the painting stratum was the desire to make the unique find, miraculously preserved, visible as soon as possible. Following the cleaning, the paintings were uncovered using a solution of

\footnotetext{
${ }^{29}$ For this project in detail, see: The Space of Synagogues: Jewish History, Common Heritage and Responsibility https://www. lvivcenter.org/en/space-of-synagogues/ (accessed 21 November 2019).

${ }^{30}$ The history of the clearing of the artwork is detailed in the article by Yuliy Lifshitz, who organized this work, see: АИФШИЦ, ref. 12.
} 


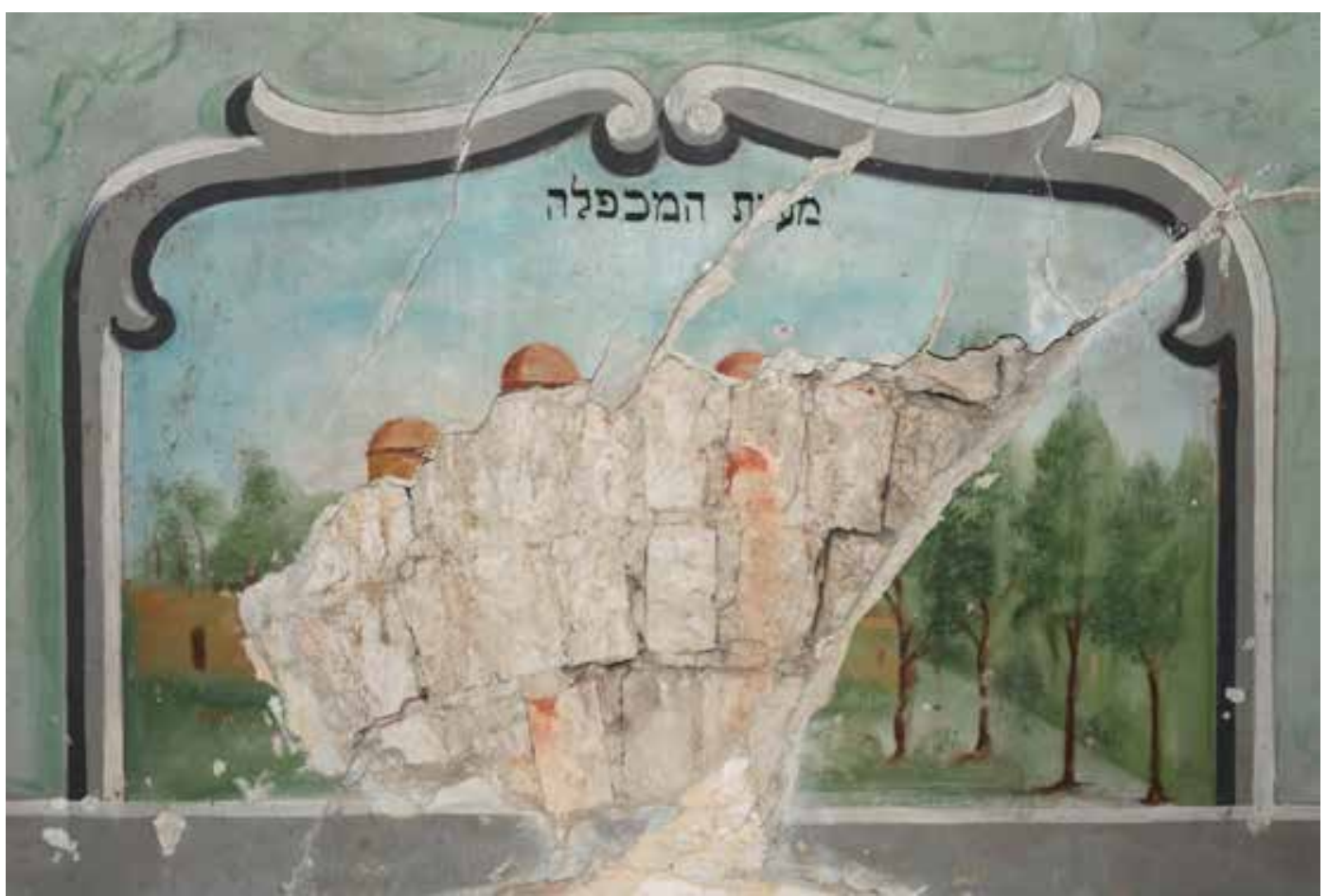

Figure 9: Novoselitsa. New Great Synagogue. The Tomb of the Patriarchs in Hebron, wall paintings, 1919-1920. Photo by Anna Yamchuk, 2015

pinene and plant oil, thus recovering the images' original vividness. The work was performed in a professional manner, and achieved its goal. But the outcome was that the paintings were left exposed, whereas previously the uppermost layer of chalk had, for many decades, protected them from destruction. Debates and discussions about putting the ensemble on display in the future have not yielded any conclusive results. One of the options, proposed by the private owner of the building, was to conserve the paintings in the same building, which was intended to serve as a cultural institution after renovation. A second option, put forth by Jewish agencies, was to transfer the stratum with the paintings to Chernivtsi, the regional capital, which has an active Jewish community and a museum - in fact, a variety of institutions generating a "museum-going stream" of visitors. Settling on a solution involves tackling questions of an organizational, financial and technical nature which apparently still remain open. Today, thanks to the dilapidation of the building, the paintings are in a critical condition; some of the fragments have been lost forever (Figures 8, 9). The building's owner, concerned about the prolonged inaction, has meanwhile started renovation work on his property on his own. At present it is difficult to guess what this monument's fate may be.

\section{Using old painting motifs in new decoration}

This approach was taken in the reconstruction of the synagogue residence of the Tzaddik Israel Friedmann in Sadygora, which was built in the late nineteenth century, between 1860 and 1890 (exact date unknown). The building's reconstruction, which took place between 2012 and 2016, was led by Mikhail Krayz, who worked in close interaction with the descendants of the Sadygora Tzaddik. The project was the upshot of perennial discussions and deliberations about 


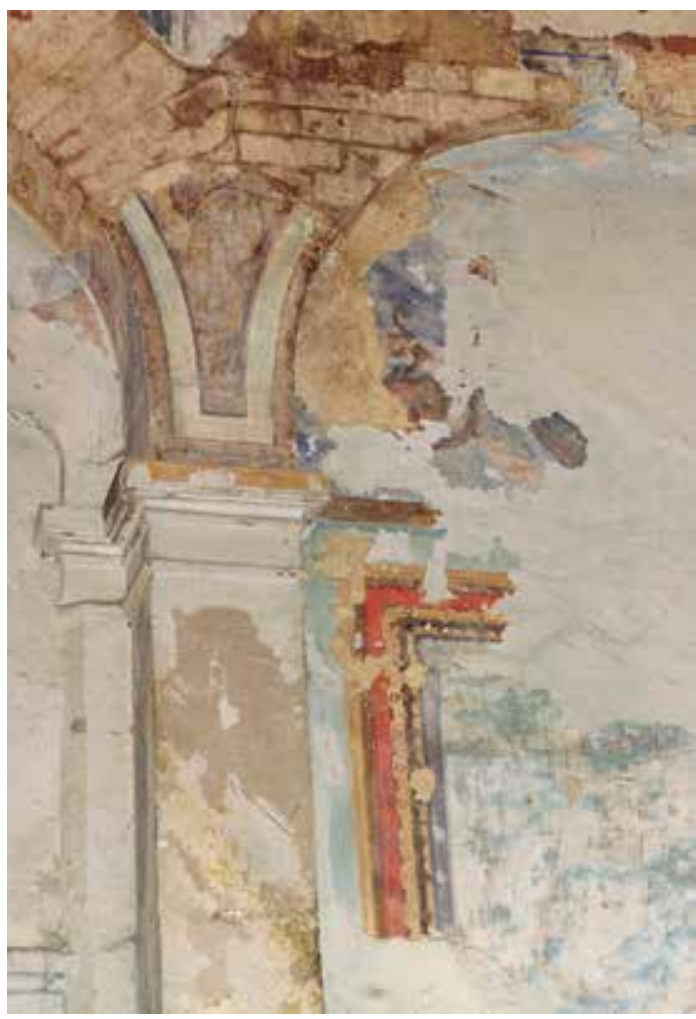

Figure 10: Sadygora (now part of Chernivtsi). Former Rabbi Israel Friedmann's Synagogue. Traces of wall-paintings in the ruined building.

Photo by Eugeny Kotlyar, 2002

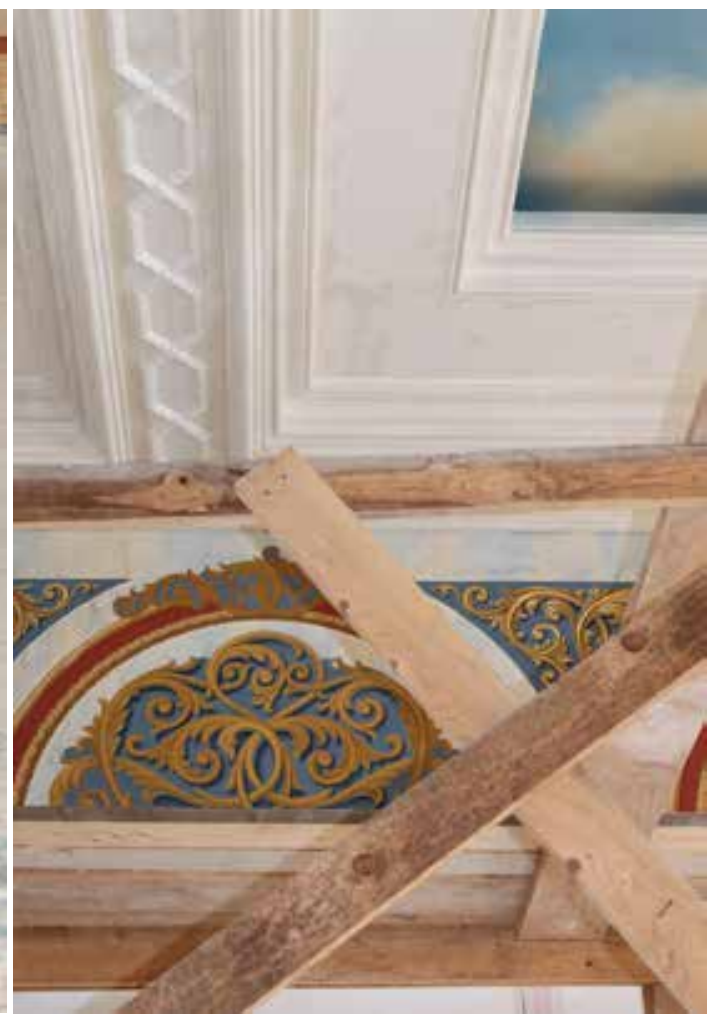

Figure 11: Sadygora (now part of Chernivtsi). Rabbi Israel Friedmann's Synagogue. A new synagogue decoration. Photo by Eugeny Kotlyar, 2016

the question of restoring the centre of Sadygora Hasidism for pilgrims who are also followers of the movement. ${ }^{31}$ The very meagre material that remained for the renovators to draw on from the former luxuriously decorated synagogue of one of the most powerful nineteenth-century Hasidic traddiks meant it was only possible to form only an overall sense of the styles and the colour schemes used in the decorative wall paintings, and to take in little more than the spirit of the ornamentation. Fragments of painted engaged frames and curved ribbon-like shafts with their inner fields partly filled with climbing acanthus were adopted as basic motifs from the old decoration in creating the new paintings. This part of the decoration, reconstructed from the legacy of the past, also dictated the general colour scheme (Figures 10, 11). The scheme was thoroughly integrated into the new design of the interior of the interior, which combined traditional elements with postmodernism. Aharon Ostraikher, mentioned above in connection with the restoration of Schekovitzka Synagogue, used the motif of a blue sky with clouds, executed in a photorealistic manner, to decorate the coffered ceiling. This modern approach was combined with traditionalist stained-glass windows on the theme of the Twelve Tribes of Israel by the Chernivtsi artist Anatoly Fedirko.

\footnotetext{
${ }^{31}$ For this project in detail, see: Садгірську синагогу відкрили у Чернівцях після реставраціï, https://acc.cv.ua/ news/chernivtsi/sadgirsku-sinagogu-vidkrili-u-chernivcyah-pislya-restavraciyi-foto-15606 (accessed 22 November 2019).
} 
It gladdens the heart that the thoughtful, integrated approach to the reconstruction of the building itself, was also manifested in the architecture of the new ohel of Israel Friedmann's family and his descendants at the local Jewish cemetery. In these examples, we can see a single architectural complex beginning to take shape, becoming the modern symbol of RuzhinSadygora Hasidism, underscoring the status of this former Chernivtsi suburb. The approach evidences more than just a positive experience of reconstruction work of this type; it also shows ways of combining old heritage with modernity. This is thanks both to the strategy of meticulous recovery of the synagogue's architectural decoration - which involved the development of special new techniques for restoring bricks and stucco work - and to a pluralistic approach towards the interiors and decorations which brought together distinct historical eras in the synagogue's history and the contexts of memory which are bound up with them.

The approaches mentioned run up against a cluster of issues connected with preserving old paintings in their original condition; a lot depends on the condition, status and ownership of the buildings in question. In cases when the building is in use as a synagogue, the community itself often prefers to aim for a comfortable renovated prayer space, rather than an authentic monument bearing marks of destruction and decay. If the building is in a neglected condition, the question arises as to whether it is best to continue using it or to remake it into a cultural institution such as a museum or library - especially if the building is privately owned. In the case of the Novoselitsa synagogue, by leaving this problem unaddressed, it could be said that we have acquired this monument as an object of academic discourse, but may well lose it as a tangible item in reality. Finally, if the synagogue is managed by the community, with its paintings preserved without suffering the same ruin as in the synagogue in Khust, then it needs to be entrusted to international care, and efforts need to be coordinated between the building's owners and the community leadership to ensure the paintings' conservation. At the present stage, the options available make it problematic to undertake the costly transfer of a largescale painting stratum from a decaying building to a facility that is specially adapted for this purpose, as is normally done in other countries. Even so, possibilities of this kind should not be dismissed out of hand, considering that very few surviving works remain. It is increasingly evident that these surviving works also cannot be left to the arbitrary discretion of property owners and their individual initiatives. Whatever the decision in each individual case, it appears to be of paramount importance to set up a separate register of monuments of this kind, to enter them in an international project, and to jointly provide for their conservation.

\section{Ways of displaying synagogue decoration}

Given the real situation in Ukraine today, it needs to be made clear that the issue of restoring to the old synagogue paintings an aspect appropriate for a historical monument, as well as achieving this for former synagogue buildings overall, is objectively bound up with a series of issues. First of all, there has been a drastic drop in Jewish population figures in Ukraine, and in the level of Jewish social activism, especially in more modest-sised towns - a circumstance which makes it difficult to obtain financing for projects of this kind, as well as calling into question whether these buildings will be made use of later. Second, without international support, it is extremely difficult to repurpose these buildings to make them into city museums - as has been done, for instance, in Poland, where the buildings were subsequently handed over to be managed by the state. Third, there is insufficient openness about these processes along with the failure of all interested parties to come together to solve these issues. Overall, sadly, 
we confirm that the surviving works are in most cases doomed to vanish. Thus, along with the importance of eternalising the works that have already gone, the predicament of the surviving pieces compels us to search for other ways of preserving this heritage as a part of Ukraine's cultural tradition, and to think about transferring it to a different, more reliable carrier of memory. We are referring to the various means of museum-based preservation and display of this kind of heritage. Similar problems occupy experts throughout the world today, and various ways of addressing the question have been offered. This field has developed its own store of accumulated experience and perspectives, from which we need to single out the principal guiding elements and directions.

1. Making models of old synagogue interiors containing wall paintings for Jewish museums

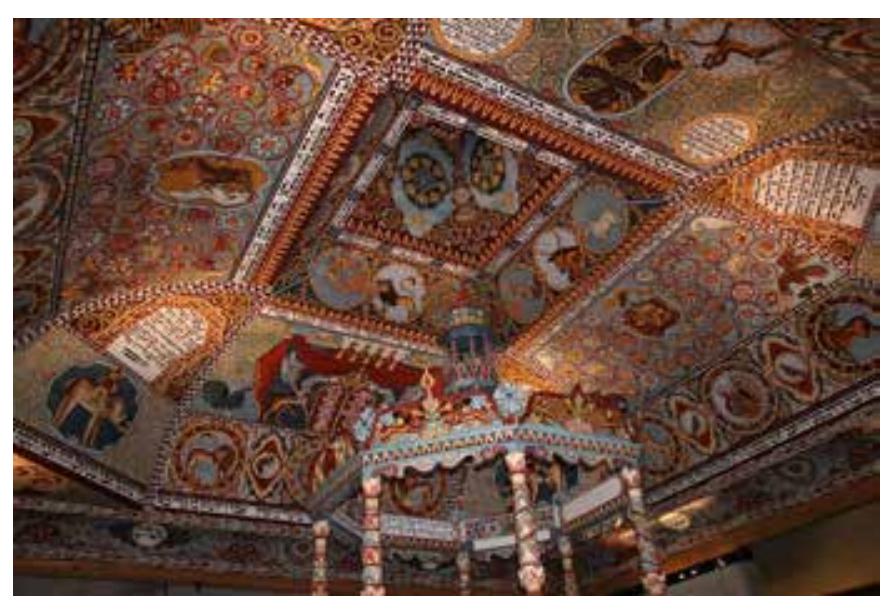

This approach can be traced in two well-known copies of synagogue wall paintings from the first half of the eighteenth century, recreated using wooden constructs. These are replicas of the ceiling paintings from the Khodoriv Synagogue (1977, James Gardner Studios, London) stored in the Diaspora Museum in Tel Aviv, and the vault and bimah paintings from Gvizdetz (20112014, Handshouse Studio, Norwell, US) ${ }^{32}$ at the POLIN Museum

Figure 12: Replica of the bimah and vault paintings from Gvizdetz. Synagogue. Warsaw. POLIN Museum of the History of Polish Jews. 2013-2014. Photo by Eugeny Kotlyar, 2014 of the History of Polish Jews in Warsaw (Figure 12)..$^{33}$ Both synagogues were formerly located in lands which are today part of Ukraine. The new models recreate the paintings in the synagogues, which were documented prior to WWI in Alois Breyer's photograph collection - now held by the Tel Aviv Museum of Art. ${ }^{34}$ The models' authors also attempted to reconstruct the colour palette of the paintings, taking as their point of departure old copies which were made during the pre-WWI period. ${ }^{35}$ An important element of the program to reconstruct the paintings on the synagogue's domed ceiling was its educational aspect, associated with the openness and the popularisation of the project. While works on the dome were being undertaken in

\footnotetext{
${ }^{32}$ For the project in detail, see: Replicating the Gwozdziec Wooden Synagogue http://www.handshouse.org/\#/gwozdziec/ (accessed 22 November 2019)

${ }^{33}$ On the creation of a replica of the wooden synagogue in Gvizdetz for the POLIN museum, see: https://www. polin.pl/en/news/2014/03/18/gwozdziec-synagogue-we-are-done (accessed 22 November 2019)

${ }^{34}$ The Tel-Aviv Museum of Fine Arts, the William G. Goldenberg Drawings Room, the Alois Breyer Photographs Collection of Wooden Synagogues from the Department of Engravings and Drawings. The author wishes to express his gratitude to Mrs Emmanuella Kahlo, the keeper of the foundation, for her assistance in work with this collection in 2012. See also: GOLDMAN-IDA, Batsheva (ed.). Alois Breyer, El Lissitrky, Frank Stella-Wooden Synagogues, Tel-Aviv Museum of Art, 10 July- 18 October 2014. Exhibition catalogue. Tel-Aviv, 2014, p. 38-77, $127-129$. ${ }^{35}$ PIECHOTKA, Maria and Kazimerzh. Heaven's Gates. Wooden Synagogues in the Territories of the Former Polish-Lithuanian Commonwealth. Warsaw: Krupski i S-ka, 2004, p. 113-159.
} 
2011-2013, seminars were conducted in eight Polish cities (Sanok, Zheshuv, Cracow, Vrotzlav, Gdansk, Seynakh, Kazimezh and Schebzheshin) where students worked side-by-side with an international team of historians, architects and masters specializing in traditional carpentry and polychrome painting. The seminars took place in each city's synagogue, with local residents also invited to join and acquaint themselves with the values of the project, with Jewish culture and with the past of their city. Practical work on the model of the synagogue's domed ceiling was also in progress during these encounters. The direct interaction between the Studio's workers, the Association of the Polish Jewish Historical Institute and the Museum of the History of Polish Jews ensured the emergence of an effective strategy for working on the project, brought a level of professionalism to the discussions and increased the impact on the public.

2. Using motifs taken from synagogue paintings in Jewish communities' new construction projects

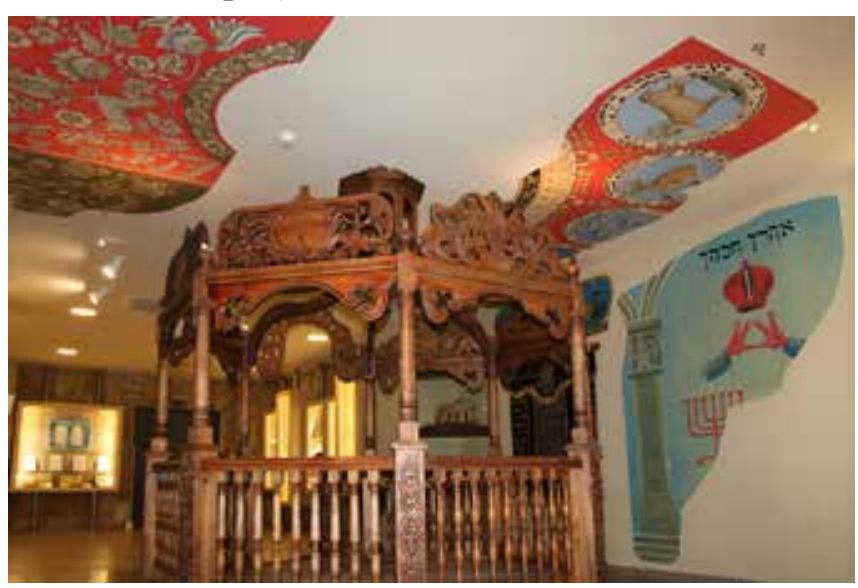

Figure 13: Dnipro. Tekumah Jewish Center, Memory of the Jewish People and the Holocaust in Ukraine Museum.

Photo by Eugeny Kotlyar, 2012
This approach is expressive of the creative rethinking of tradition. The earliest example of this in Ukraine was the Memory of the Jewish People and the Holocaust in Ukraine Museum at the Tekumah Jewish Center in Dnepropetrovsk (now Dnipro) in 2012 (Figure 13). The design of the hall devoted to a display of the traditional lifestyle of Eastern European Jewry incorporates a collage of fragments taken from synagogue wall paintings in Khodoriv, Chernivtsi, Khorb and other places, to produce a cumulative impression of a traditional synagogue's liturgical space. The head artist of the museum is Victor Gukaylo. Our next example is Shtetl, the Jewish café in the Beit Dan Jewish Cultural Center in Kharkiv (2002, design by Eugeny Kotlyar). The popular zodiac motif from the Khodoriv synagogue wall paintings is incorporated into the decoration scheme as an expression of Eastern European Jewish culture. The Khodoriv zodiac motif also appears in a third context: decorating the synagogue in the Jewish community centre in Sumy, which opened in 2005. Here it appears in an altered colour scheme and with a different compositional structure. The twelve compositions are each displayed separately in a round frame, with three insets on each of the four walls (also designed by Eugeny Kotlyar). These instances exemplify the transference of synagogue decoration as part of the Jewish cultural tradition into a variety of the Jewish community's constructions: museums, cultural centres and synagogues. Such a presentation medium makes it possible to establish the works in the cultural consciousness of the generation of today, even though this type of presentation is far from being scholarly. 
3. Exhibition projects
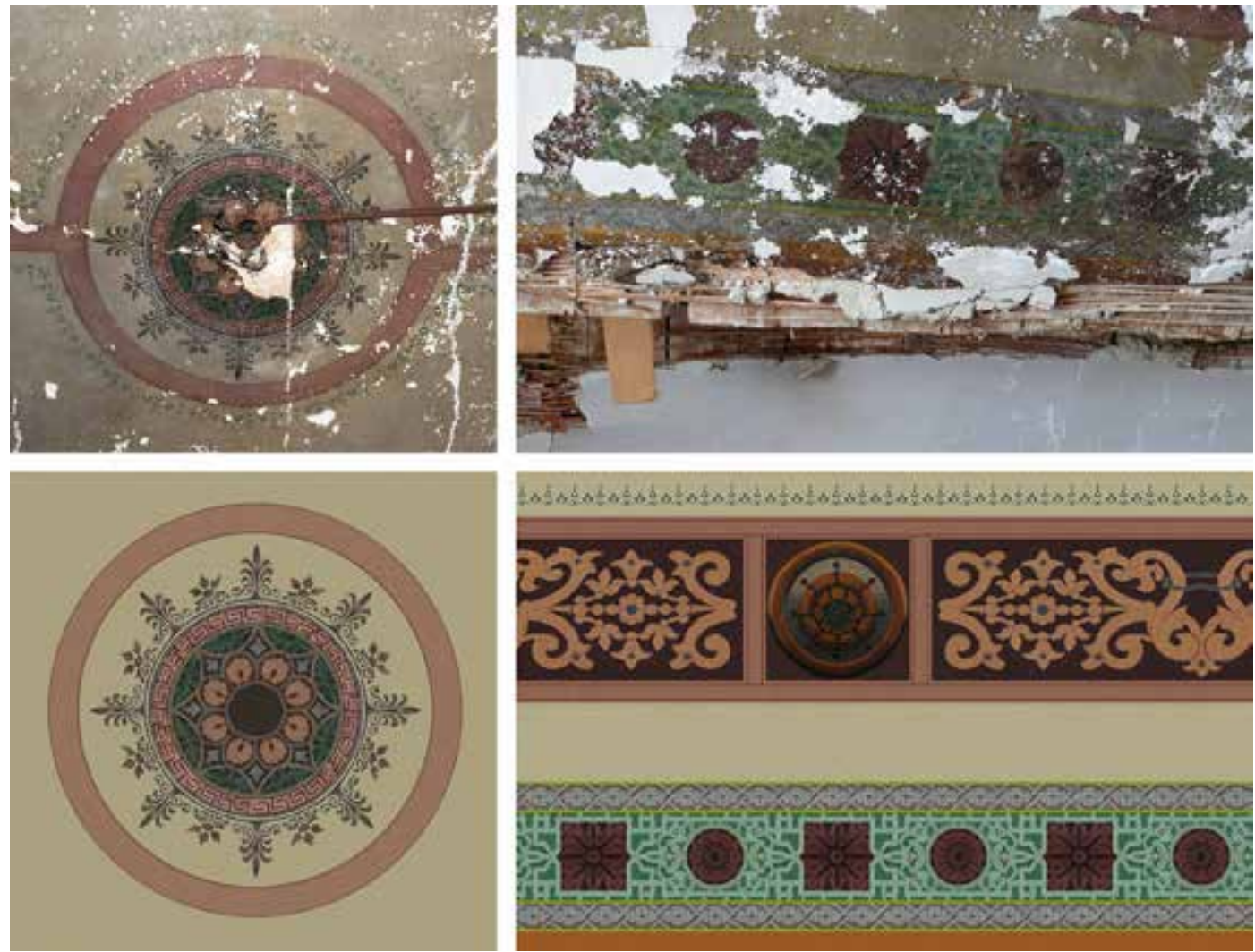

Figure 14: Chernivtsi. Chevra Tehilim Synagogue. Digital reconstruction of the damaged ceiling paintings. Computer graphics by Eugeny Kotlyar, 2015

Old and modern photographs of synagogue wall and ceiling paintings, along with studies, hypotheses and reconstructions, provide excellent material and a set of instruments for displaying this heritage in appealing exhibitions that can be creative, academic or educational. The only instance of this in Ukraine to date has been the project How Goodly Are Thy Tents, Ob Jacob... Synagogue Wall Paintings from Bukovina, which ran in 2015-16 and was curated by the present author in cooperation with the Chernivtsi Museum of Jewish History and Culture in Bukovina (project leader Mykola Kushnir), with research support provided by the leading Israeli specialists Prof. Ilia Rodov (Bar-Ilan University) and Dr Vladimir Levin (Center for Jewish Art at the Hebrew University of Jerusalem).

The project involved eight Bukovina synagogues, four each from the territory of today's Romania and Ukraine. Each site was documented by a set of materials which included the painting programme, photographic reconstructions, and twelve descriptions of the most representative compositions in the paintings. Articles providing general background information made it possible to introduce the regional specificity of this tradition.

The special highlight of the project proved to be the development of two-dimensional reconstruction plans of the painting schemes and photographic displays. This made it possible to eternalise the surviving groups of paintings and make them visually accessible. In some cases, 


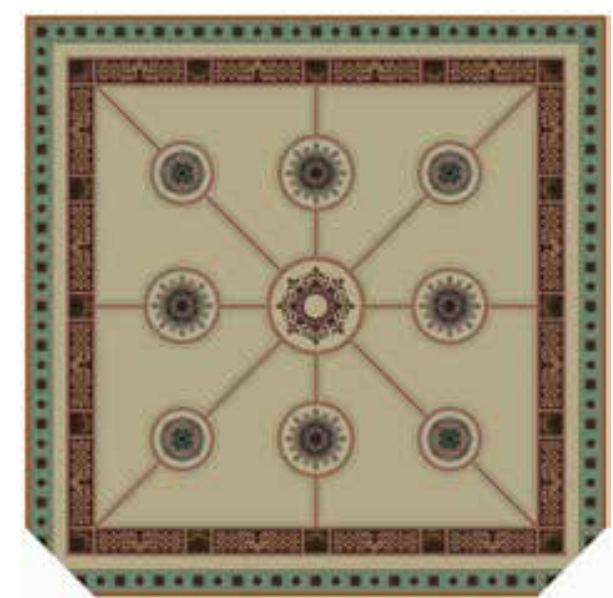

Figure 15: Chernivtsi. Chevra Tehilim Synagogue. Digital reconstruction of the ceiling paintings. Computer graphics by Eugeny Kotlyar, 2015

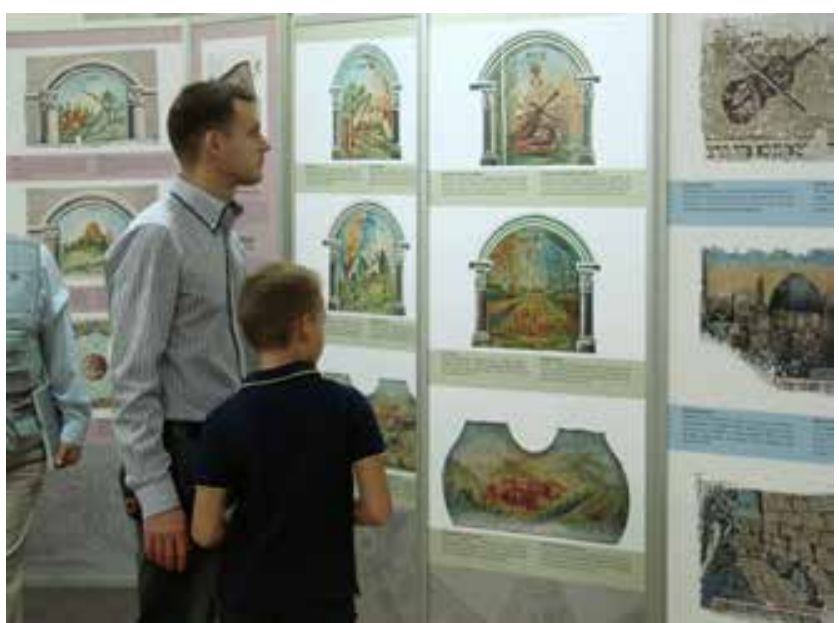

Figure 16: Chernivtsi. The opening of the Wall Paintings in Bukovini-worth giving thought to whether a an Synagogues exbibition. Art-Sweet Gallery. October 2016. Photo by Eugeny Kotlyar

as in the ruins of Beit Tehilim Synagogue in Chernivtsi, we were able to reconstruct part of a painting that had been all but lost. Certain elements of the painting were recreated based on the surviving details of the ceiling decoration; from this, the original appearance of the painted ceiling re-emerged (Figure 14). Superimposing the lost fragments upon the result produced a photo display which enabled the viewer to envision the ceiling in its original form (Figure 15) and appreciate its condition at present. Similar work on other parts of the paintings enabled us to recreate the painting scheme, except where compositions had been completely lost. The same kind of work was carried out for other synagogues which were in varying states of dilapidation. The result was a comprehensive exhibition catalogue ${ }^{36}$ and a transformable mobile display. The first viewers saw it in the fall of 2016 in Chernivtsi (Figure 16) and Kharkiv; in early 2017 the exhibition moved to Kiev and it will in future be on display in Odessa, Bucharest, Vilnius and other cities. Of outstanding importance among the objectives achieved by the project is its success in demonstrating the specificity of synagogue wall paintings in Bukovina in the general context of the tradition of Eastern European synagogue decoration.

This experience suggests it is project along these lines might be implemented involving synagogue wall paintings throughout Galicia. Today we can already begin to pinpoint the particular features of these works, which are bound up with the influence of the Vienna school of decorative painting on the Eastern Galician region. ${ }^{37}$ The Lviv school emerged as a result of this influence, leading to the appearance of local masters who created synagogue wall and ceiling paintings. ${ }^{38}$ The styles defining this regional tradition can be appreciated in its leading preserved example: the wall paintings in

\footnotetext{
${ }^{36}$ KUSCHNIR, ref. 9.

37 КОТАЯР, Евгений. Восточноевропейская традиция росписей синагог и ее региональные центры на исторических землях Украины. К постановке проблемы. In: Вісник Харківської державної академії дизайну і мистецтв. Харків: ХАААМ, 2010, nо. 8, сс. 76-84.

${ }^{38}$ Among them: the Fleck brothers, Sigmunt Balk, Erno Erb, Maksimilian Kugel, and others. See: ГАЕМБОЦКАЯ, Галина. Художники-евреи Аьвова первой трети ХХ века. Жизнь, творчество, судьба. Аьвов, 2015, р. 29, 129, 166-169.
} 


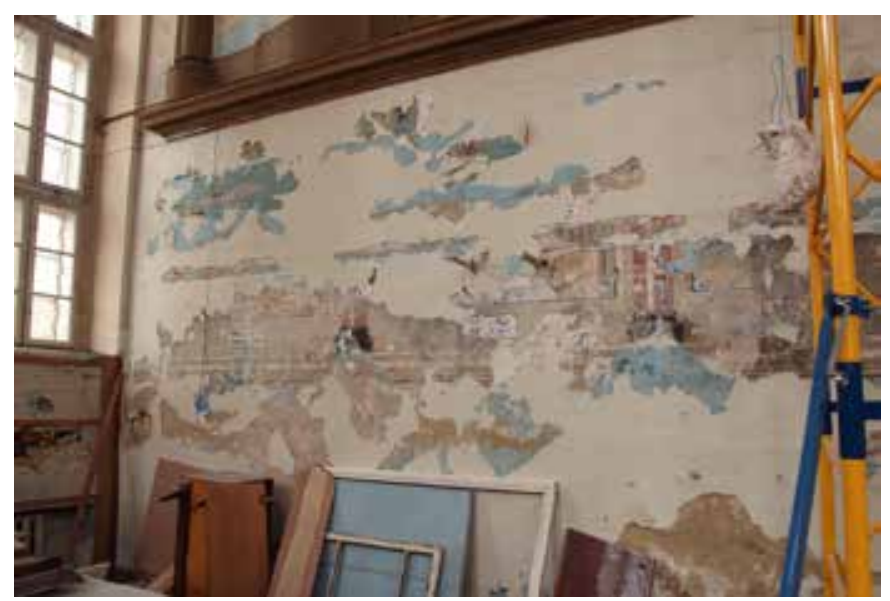

Tzori Gilead Synagogue in Lviv, described above. Despite the recent loss of the original and the fact that the paintings had to be entirely redone in 2006-2007, we can confidently make some claims about its programme, iconography and artistic style. The paintings were created in 1936 by the artist Maksimilian Kugel, a member of the workshop circle associated with the Flack brothers. These masters painted Figure 17: Lviv. Yakub Glanzer's Shul Synagogue, 1844. Traces of wall-synagogues throughout Galicia, ${ }^{39}$ -paintings in the ruined building.

Photo by Eugeny Kotlyar, 2016 leaving behind them numerous sketches for synagogue wall and ceiling paintings in a distinctive style. Another significant example to flesh out the regional context of the tradition could be the only partly uncovered paintings in the Yakub Glanzer's Shul in Lviv. ${ }^{40}$ The synagogue was built in 1844, rebuilt in 1912, and underwent a complete renovation after the pogrom of $1918 .{ }^{41}$ The anonymous paintings, still concealed beneath the plaster, can presumably be associated with the time of this complete overhaul (Figure 17). The building belongs to the Jewish community; unlike the predicament of the Novoselitsa synagogue, its paintings do not need to be transferred to any other location and the future fate of the building is not a cause for concern. Clearing the painted stratum and its subsequent preservation may yield valuable information about the painting design, showing the connection between these decorations and the local traditions of the region. The synagogue paintings in Buchach, mentioned earlier, can also be coordinated with this category; they also need clearing, expert documentation and conservation, as a matter of urgency. Unfortunately, work of this kind is not possible in other regions of Ukraine, due to the absence of surviving artefacts.

Projects of this kind present rich content for exhibitions; this can include archival materials and research conducted in the pre-war years, as well as the opportunity to combine research projects with creative exhibitions following fieldwork expeditions and art plein airs. Some examples of projects along these lines are already available, such as the Jewish Atlantis project, (curator Eugeny Kotlyar, in collaboration with Hillel, a Jewish student organization). Even though it did not directly concern synagogue paintings, but rather dealt with the overarching theme of creative appropriation of the heritage of the shtetl and the former Jewish Pale of Settlement, it provided modern artists' vivid reflections on the overarching theme, with the

\footnotetext{
${ }^{39}$ Ibid., p. 390-391.

${ }^{40}$ We are grateful to Aleksandr Nazar, leader of the Sholom Aleichem Lviv Society of Jewish Culture, for his gracious assistance in the examination and photographing of the synagogue, as well as the discussion of ideas and perspectives of reconstruction and future use of the building for community needs.

${ }^{41}$ Синагоги України, ref. 8, p. 95-96.
} 
E. Kotlyar - L. Sokolyuk - T. Pavlova: Synagogue Decorations in Present-Day Ukraine...

Jewish context becoming part of the artists' list of thematic foci and creative experience. ${ }^{42}$

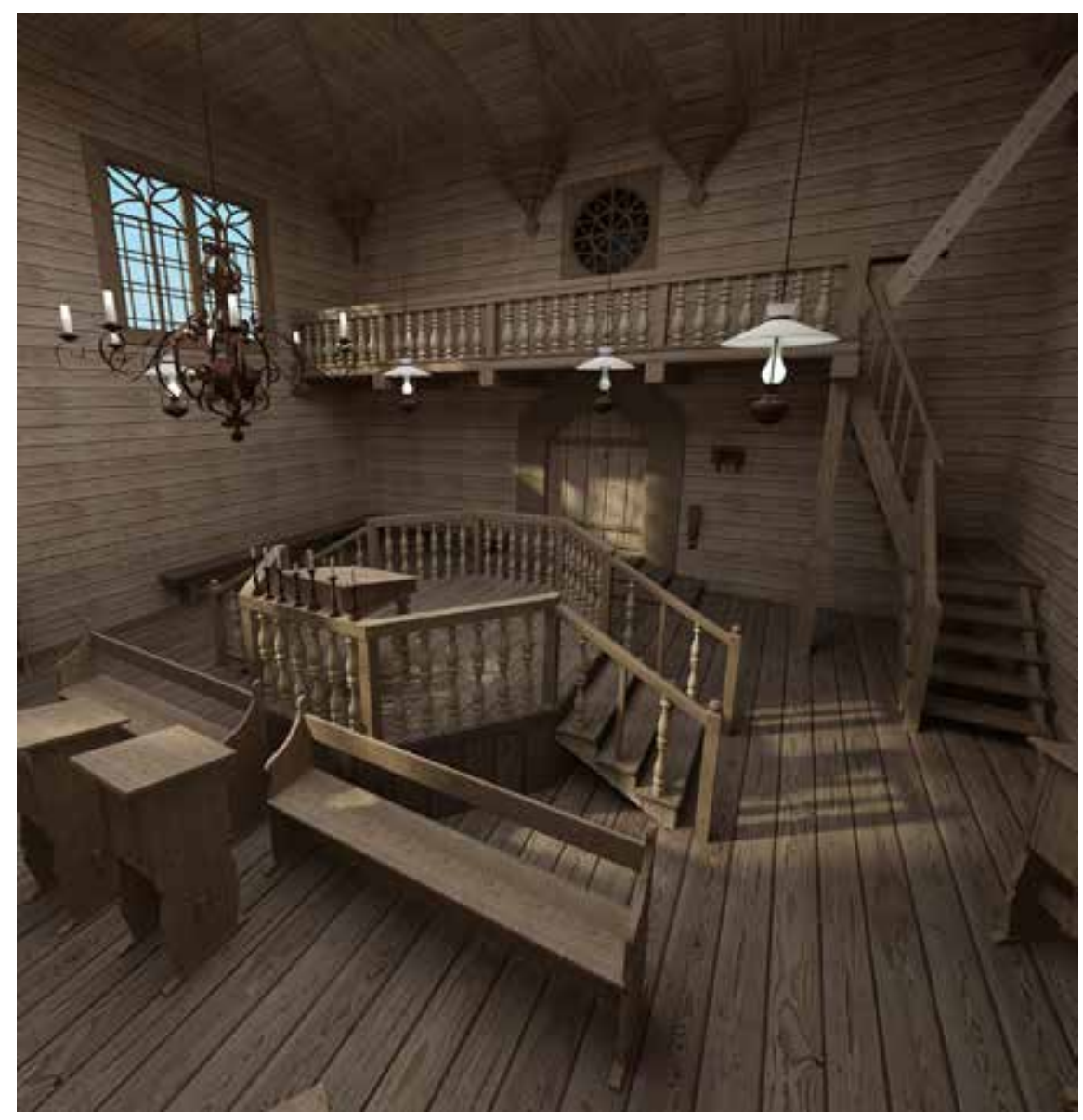

Figure 18:

A digitised model

of the interior of

the wooden syna-

gogue in Smotrych, mid-eighteenth

century. Model by

Sergey Biryukov

and Eugeny

Kotlyar, 2011

\section{3D Multimedia presentations}

In the context of Ukranian synagogue paintings, this presentation format belongs, for the time being, with perspectives for the future, but it is a thoroughly realistic means of modelling both surviving and lost items in space. As such, it has enormous educational potential. Based on accumulated experience in creating replicas of synagogue interiors by means of paintings and $2 \mathrm{D}$ reconstructions, it seems feasible to make use of modern multimedia technologies to design 3D presentations with interactive navigation. The Center for Jewish Art at the Hebrew University of Jerusalem and the Beit Tefilah Center at the Technical University of Braunsweig have some experience to date in developing computerised models of synagogues. This experience enabled a team, with which this author was involved, to develop a digitalised model of the wooden synagogue built in the eighteenth century in Smotrych (Figure 18). It seems quite feasible to "superimpose" painting displays done by hand or by computer on the modelled parts of buildings, especially considering that we have a number of old photographs

\footnotetext{
${ }^{42}$ KOTLYAR, Eugeny (ed.). "Jewish Atlantis". World of Shtetl in the Works of Kharkov Artists. Exhibition of Visual Arts in Conclusion of Project "Neshama: Through Art to Heart". Exhibition catalogue. Kharkov: Center for Eastern Studies at Kharkov State Academy of Design and Arts, 2012.
} 
at our disposal. Certain compositions which did not make it into the frame of any of the historic photographs or fragments which have been lost can be indicated by special masking camouflage; the painted compositions most likely to have been there can also be indicated on the walls and vaulted ceilings. Displayed in a real architectural space, the paintings can open up and move, following the camera as it conveys a view of the synagogue's interior space. Using a system of interactive references and navigation, the semantics and iconography of specific compositions can be explained and presented to view, along with translations and interpretation of signs and inscriptions, the gimatrias of recorded dates, and so on.

\section{Conclusion}

This study - which presented the historical heritage and modern condition of synagogue wall paintings, along with methods and examples of their preservation, current and future possible practices, and various approaches and technologies for their presentation - suggests the following considerations. While the quality and condition of the wall paintings will inevitably have an effect on the possible strategies for preservation, as will the pragmatic reality of what is actually possible - and in Ukraine today, we are still far from the level of financing, technology and public enthusiasm seen abroad - there are nevertheless two universal considerations that need to be borne in mind. First, authentic strata must be studied as historical artefacts; they must be preserved, and sealed in their current condition either in situ or in a museum space especially created for this. The idea of creating a museum of synagogue wall paintings in one of the renovated synagogues has put forth by the VAAD of Ukraine, but so far no action has been taken to follow up on the initial proposal. ${ }^{43}$ Second, wall painting decoration, as an area of cultural memory and living tradition, is not only a memorial (that is, an object and a repository of memory) but also an instrument of memory. Memory itself, according to Jan Assmann, not only preserves and recreates the past, but also reorganizes it "by means of changing contextual frameworks of the ever-surging-ahead present." ${ }^{4}$ A carefully thought through use of this instrument, taking advantage of technologies that are available today or those which will become available in the future, will make it possible to preserve this memory of the past objectively and correctly, without the imposition of additional layers or distortions, thus establishing a bond between eras and generations. It would appear that exhibitions and multimedia formats are the most accessible and effective presentation formats for the lost and the disappearing phenomenon of synagogue decoration in Ukraine today. Even so, it is in all cases important to distinguish the object itself from the various types of interaction with it and the different kinds of interpretation, so as not to deprive future generations of the opportunity to work with a primary source. The openness of these projects to united international involvement - and the integration of Ukrainian expertise in the international process of studying and preserving synagogue decoration as a part of the heritage of humanity - is an essential precondition for making this possible.

\footnotetext{
${ }^{43}$ We are indebted to Dr Joseph Zissels for providing me with this information.

${ }^{44}$ ACCMAHH, ref. 2, c. 43.
} 
E. Kotlyar - L. Sokolyuk - T. Pavlova: Synagogue Decorations in Present-Day Ukraine...

\section{References}

ASSMANN, Jan (2004). Pisjmo, pamyatj o proshlom i politicheskaya identichnostj v vysokix kuljturah drevnosti [Cultural memory and early civilization: Writing, remembrance, and political imagination] (transl. from German by M. M. Sokoljskaya). Moskva: Yazyki slavyanskoj kultury [Languages of Slavic Culture]. ISBN 5944571764.

BEIZER, Michael (2002). Our Legacy: The CIS Synagogues, Past and Present. Jerusalem: Gesharim - Moscow: Bridges of Culture. ISBN 5932730854.

BERNSTEIN-WISCHNITZER, Rachel (1914). Iskusstvo u evreev v Poljshe i Litve [The Art of Jews in Poland and Lithuania]. In: Istoriya evreev v Rossii [History of Jews in Russia]. Moskva: Mir, 1914, vol. XI: Istoriya evrejskogo naroda [History of Jewish People], vol. 1, p. 390-405.

DORFMAN, Rivka and Ben-Zion (2000). Synagogues without Jews and the Communities that Built and Used Them. Philadelphia: The Jewish Publication Society. ISBN 0827606923.

FILVAROV, Genrikh (1995). Istoriko-gradostroitel'nye osobennosti sokhraneniya yevreyskogo kulturnogo naslediya v Ukraine [The Special Historical and Urban Architectural Features of Preserving the Jewish Cultural Heritage in Ukraine]. In: Jewish History and Culture in Ukraine, papers of the conference, Kyiv, 8-9 December 1994. Kyiv: Association for Judaic Studies, p. 193-195.

GLEMBOTSKAJA, Galina (2015). Hudozhniki-evrei Lvova pervoj treti XX veka. Zhiznj, tvorchestvo, sudjba [The Lviv artists of the first half of the twentieth century. Life, works, fate]. Lviv: TzOV "Vydavnytstvo Stavropihion," 2015. ISBN 9789662037098.

GOLDMAN-IDA, Batsheva (ed.) (2014). Alois Breyer, El Lissitzky, Frank Stella-Wooden Synagogues. Tel-Aviv Museum of Art, 10 July - 18 October 2014. Exhibition catalogue. TelAviv. ISBN 9789655390971.

GRUBER, Samuel (ed.) (2005). Jewish Cemeteries, Synagogues and Mass Grave Sites in Ukraine. The Report. Washington: U.S. Commission for the Preservation of America's Heritage Abroad, 2005.

KAL'NYTSKYI, Mikhail (2012). Evreiskie adresa Kieva [Jewish Addresses of Kiev]. Kyiv: Spirit and Letter, p. 133-142. ISBN 9789663782225.

KHAIMOVICH, Boris (2008). "The Work of Our Hands to Glorify". Murals of Beit Tfilah Benyamin Synagogue in Chernovits: Visual Language of Jewish Artist. Kyiv: Spirit and Letter. ISBN 9789663780801.

KHAIMOVICH, Boris (2016). The Murals in the Novoselitsa Synagogue. Kyiv: Spirit and Letter. ISBN 9789663784540.

KOTLYAR, Eugeny (ed.) (2012). "Jewish Atlantis". World of Shtetl in the Works of Kharkov Artists. Exhibition of Visual Arts in Conclusion of Project "Neshama: Through Art to Heart". Exhibition catalogue. Kharkov: Center for Eastern Studies at Kharkov State Academy of Design and Arts. ISBN 9789668106644.

KOTLYAR, Evgenij (2003). Obraz Evrejskogo Renessanca. K rekonstruktsii Glavnoj sinagogi Kieva [Images of Jewish Renaissance. To Reconstruction of the Main Synagogue of Kiev]. In: Vaterpas 45. Kharkiv, p. 34-38.

KOTLYAR, Evgenij (2010). Vostochnoevropejskaya traditsiya rospisej sinagog i ee regionaljnye tsentry na istoricheskih zemlyah Ukrainy. K postanovke problemy [The Eastern European tradition of synagogue wall painting and its regional centers in the historical lands of Ukraine: To the formulation of the problematic]. In: Bulletin of the Kharkiv State Academy of 
Design and Arts 8. Kharkiv: KSADA, Center for Eastern Studies, p. 76-84. ISSN 19936400. KOTLYAR,Evgenij(2012). RospisisinagogSevernojBukovinyvkontekstevostochnoevropejskoj traditsii [Wall Paintings of the Synagogues of Nothern Bukovina in the Context of Eastern European Tradition]. In: CHERNOIVANENKO, Vitaly (ed.) Judaica Ukrainica 1. Kyiv: The Publishing Center of Kyiv-Mohyla Academy, p. 227-263.

KRAVTSOV, Sergey (2011). Di Gildene Royze. The Turei Zahav Synagogue in L'viv, vol. 3. St Petersberg: Michael Imhof Verlag. ISBN 9783865681386.

KUSCHNIR, Mykola, KOTLYAR, Eugeny, YAMCHUK, Anna (eds) (2016). "How Goodly Are Thy Tents, O Jacob..."Wall Paintings in Bukovinian Synagogues. Catalogue of the Exhibition. Chernivtsi-Kyiv: The Chernivtsi Museum of the History and Culture of Bukovinian Jews; Spirit and Letter. ISBN 9789663784649.

LIFSHITZ, Yuliy (1994). Naturnye issledovaniya zdaniya sinagogi XVII - XIX veka v Satanove Khmeljnitskoj oblasti [Living Research of Synagogue Building (seventeenth - nineteenth century) in Satanov, Khmelnitsky Oblast]. In: LUKIN, Benjamin et al. (eds) Istoriya evreev na Ukraine iv Belorussii: ekspeditsii. Pamyatniki. Nahodki [The History of Jews in the Ukraine and Byelorussia. Expeditions. Monuments. Finds]. St Petersburg, vol. 2, p. 120-127.

LIFSHITZ, Yuliy (2010). Na grani zabveniya [On the Verge of Oblivion]. In: Yegupetz 19. Kyiv: Spirit and Letter, p. 401-423.

MOHITYCH, Ivan; SLOBODYAN, Vasylj (eds) (1998). Sinagogi Ukrainy: Visnyk instytutu Ukrzahidproectrestavratsiya [Synagogues of Ukraine: Bulletin of the Institute "Western Ukrainian Reconstruction Project']. Lviv: Center of Europe, vol. 9. ISBN 9669506622.

PIECHOTKA, Maria and Kazimerzh. Heaven's Gates. Wooden Synagogues in the Territories of the Former Polish-Lithuanian Commonwealth. Warsaw: Krupski i S-ka, 2004. ISBN 8386117532.

RODOV, Ilia. Ars Brevis, Vita Longa: on Preservation of Synagogue Art. In: Studia Hebraica (ed. Felicia Waldman), Bucharest: University of Bucharest, The "Goldstein Goren" Center for Hebrew Studies, 2011, no. 9-10 (2009-2010), p. 91-111.

\section{Internet sources}

Gwoździec synagogue: we are done!, accessed 22 November 2019, https://www.polin.pl/en/ news/2014/03/18/gwozdziec-synagogue-we-are-done

The Space of Synagogues: Jewish History, Common Heritage and Responsibility, accessed 21 November 2019, https://www.lvivcenter.org/en/space-of-synagogues/

Replicating the Gwozdziec Wooden Synagogue, accessed 22 November 2019, http:/ / www.handshouse. org/\#/gwozdziec/

Sadgirsjku sinagogu vidkryly u Chernivtsyax pislya resravratsii [The Sadygora Synagogue in Chernivtsi after Restoration Work], accessed 22 November 2019, https://acc.cv.ua/news/chernivtsi/ sadgirsku-sinagogu-vidkrili-u-chernivcyah-pislya-restavraciyi-foto-15606

The Catalogue of Wall Paintings in Central and East European Synagogues, accessed 18 October 2019, http:/ / ja.huji.ac.il/wpc/browser.php?mode=main

\section{Glossary}

Beit Tefilah (Hebrew): "house of prayer" - a building for Jewish religious services and a congregation of Jews who assemble for worship or religious study.

bimah, (pl. bihmas), (Hebrew): "platform" - a platform in the synagogue for reading the Torah scrolls. 
Groyse Shil (Yiddish): "Great Synagogue" - one of the common names for the main synagogue in a town.

menorah (Hebrew): "lampstand" - the seven-branched candelabrum; one of the Jerusalem Temple implements; the oldest and most important symbol of Judaism and Jewish people ohel (Hebrew): "tent" - a structure built around a Jewish grave as a sign of prominence of the deceased.

shtetl (Yiddish): "town" - a small town in Eastern Europe with a largely Jewish population; it is now used mainly to describe the Jewish townlets and the culture of East European Jews before the Holocaust.

shul (Yiddish): "school", "synagogue" (from Middle High German "schuol") - one of the names of the synagogue, common among the Hasidic communities.

traddik (Hebrew): "righteous one" - a spiritual leader of a Hasidic community; to whom the worshippers tended to ascribe outstanding qualities and mystic power. Among the Hasidim of Central and Eastern Europe, traddiks usually enjoyed an unlimited authority and influence, which often resulted in a tzadik cult. 